Systematic Review

\title{
Systematic Assessment of Diagnostic Accuracy and Therapeutic Utility of Lumbar Facet Joint Interventions
}

Sukdeb Datta, MD', Marion Lee, MD², Frank J. Falco, MD³, David A. Bryce, MD, and Salim M. Hayek, MD, PhD

From: ${ }^{1}$ Vanderbilt University Medical Center, Nashville, TN;

${ }^{2}$ The Pain Center at Affinity Health Group, Tifton, GA; ${ }^{3} \mathrm{Mid}$ Atlantic Spine \& Pain Specialists, Newark, DE; ${ }^{4}$ Advanced Pain Management, Middleton, Wl; and SUniversity Hospitals of Cleveland and Outcomes Research Consortium, Cleveland, $\mathrm{OH}$

Dr. Datta is Director, Vanderbilt University Interventional Pain Program, Associate Professor, Dept. of Anesthesiology, Vanderbilt University Medical Center, Nashville, TN. Dr. Lee is Director of The Pain Center at Affinity Health Group, Tifton, GA. Dr. Falco is Medical Director of the Mid Atlantic Spine \& Pain Specialists of Newark, DE, and Clinical Assistant Professor Temple University Medical School, Philadelphia, PA. Dr. Bryce is with Advanced Pain Management, Middleton, WI. Dr. Hayek is Chief of the Division of Pain Medicine, Department of Anesthesiology, University Hospitals of Cleveland Cleveland, $\mathrm{OH}$, and a member of the Outcomes Research Consortium, Cleveland, $\mathrm{OH}$.

Address correspondence: Sukdeb Datta, MD Pain Management Center, VA Tennessee Valley Healthcare System

1310 24th Avenue South Nashville, TN 37212

E-mail: sukdeb@hotmail.com

Disclaimer: Dr. Datta receives research support from Sucampo

Pharmaceuticals and an honorarium from Smith and Nephew.

Conflict of interest: None.

Manuscript received: 02/11/2009 Accepted for publication: 03/04/2009

Free full manuscript: www.painphysicianjournal.com
Background: Lumbar facet joints are a well recognized source of low back pain and referred pain in the lower extremity in patients with chronic low back pain. Conventional clinical features and other non-invasive diagnostic modalities are unreliable in diagnosing lumbar zygapophysial joint pain. Controlled diagnostic studies have shown the prevalence of lumbar facet joint pain in $27 \%$ to $40 \%$ of the patients with chronic low back pain without disc displacement or radiculitis, with a false-positive rate of $27 \%$ to $47 \%$ with a single diagnostic block.

Study Design: A systematic review of diagnostic and therapeutic lumbar facet joint interventions.

Objective: To determine the clinical utility of diagnostic and therapeutic lumbar facet joint interventions in managing chronic low back pain of facet joint origin.

Methods: Review of the literature for clinical studies on efficacy and utility of facet joint interventions in diagnosing and managing facet joint pain was performed according to the Agency for Healthcare Research and Quality (AHRQ) criteria for diagnostic studies and observational studies and the Cochrane Musculoskeletal Review Group criteria as utilized for interventional techniques for randomized trials.

Data sources included relevant literature of the English language identified through searches of Medline and EMBASE from 1966 to December 2008 and manual searches of bibliographies of known primary and review articles. Analysis results were performed for diagnostic and therapeutic interventions separately.

Level of Evidence: The level of evidence was defined as Level I, II, or III with 3 subcategories in Level II based on the quality of evidence developed by the U.S. Preventive Services Task Force (USPSTF) for therapeutic interventions.

Outcome Measures: For diagnostic interventions, studies must have been performed utilizing controlled local anesthetic blocks. Pain relief was categorized as at least $80 \%$ pain relief from baseline pain and ability to perform previously painful movements. For therapeutic interventions, the primary outcome measure was pain relief with secondary outcome measures of improvement in functional status, psychological status, return to work, and reduction in opioid intake. For therapeutic interventions, short-term pain relief was defined as relief lasting 6 months or less and long-term relief as longer than 6 months.

Results: Based on USPSTF criteria, evidence showed Level I or II-1 for diagnostic facet joint nerve blocks.

Based on the review of included therapeutic studies, Level II- 1 to II-2 evidence was indicated for lumbar facet joint nerve blocks with indicated level of evidence of Level II-2 to II-3 for lumbar radiofrequency neurotomy.

Limitations: The shortcoming of this systematic review of lumbar facet joint interventions is the paucity of published literature.

Conclusion: The evidence for diagnosis of lumbar facet joint pain with controlled local anesthetic blocks is Level I or II-1. The indicated level of evidence for therapeutic lumbar facet joint interventions is Level II1 or II-2 for lumbar facet joint nerve blocks, Level II-2 or II-3 evidence for radiofrequency neurotomy, and Level III (limited) evidence for intraarticular injections.

Key words: Chronic low back pain, lumbar facet or zygapophysial joint pain, facet joint nerve blocks, medial branch blocks, controlled comparative local anesthetic blocks, lumbar radiofrequency neurotomy, lumbar intraarticular facet joint injections

Pain Physician 2009; 12:437-460 
umbar facet joints are a well-recognized source of low back and referred pain in the lower extremity in patients with chronic low back pain (1-13). Facet joints are well innervated by the medial branches of the dorsal rami (14-19). Neuroanatomic, neurophysiologic, and biomechanical studies have demonstrated free and encapsulated nerve endings in lumbar facet joints, as well as nerves containing substance $P$ calcitonin gene-related peptide $(14,18-28)$.

Kalichman et al (29) evaluated facet joint osteoarthritis and low back pain in the community-based Framingham Heart Study. They concluded that there is a high prevalence of facet joint osteoarthritis in the community-based population with a prevalence of $59.6 \%$ in males and $66.7 \%$ in females. The prevalence of facet joint osteoarthritis increased with age and reached $89.2 \%$ in individuals 60 to 69 years old with highest prevalence of facet joint osteoarthritis found at the $L 4 / 5$ spinal level. Further, they showed that individuals with facet joint osteoarthritis identified by computed tomographic (CT) scan at any spinal level showed no association with low back pain. Eubanks et al (30) in a study of 647 cadaveric lumbar spines found that facet joint osteoarthritis is a universal finding. Characteristic features of osteoarthritis begin to be seen early, with more than half of adults younger than 30 years demonstrating arthritic changes in the facets, with the most common arthritic level being $L 4 / 5$. Thus, the published radiological investigations report no correlation between the clinical symptoms of low back pain and degenerative spinal changes observed on radiologic imaging studies, including radiographs, magnetic resonance imaging (MRI), CT scanning, single photon emission computed tomography (SPECT), and radionuclide bone scanning (1-3,31-33). Specifically, the association between degenerative changes in the lumbar facet joints and symptomatic low back pain remains unclear and is a subject of ongoing debate $(31,34,35)$.

Conventional clinical features are unreliable in diagnosing lumbar zygapophysial (facet) joint pain (1-7,31-33,35-46), Hancock et al (47) performed a systematic review of tests to identify the disc, sacroiliac joint, and facet joint as the source of low back pain. They found that none of the tests for facet joint pain were found to be informative $(31,36-38,48-55)$. Consequently, controlled local anesthetic blocks of the facet joint or its nerve supply are routinely employed to diagnose facet joint pain. The rationale for these blocks is that anesthetic blockade of a painful joint will abolish pain arising from that joint for the duration of the anesthetic effect, while anesthetic blockade of a nonpainful joint will not alter the pain report. The probability that the blocked joint is the actual source of pain is increased if repeating the block with an anesthetic agent that has a different duration of action reproduces the analgesic response (33). To ensure accuracy and validity, these blocks must be controlled and verified for delivery of local anesthetic agent and placebo response. Fluoroscopic guidance and controlled dual blocks eliminate or greatly reduce placebo responses. Single facet joint injections are not recommended, as they do not control for a false-positive response (1$3,31,33,36-38,51,56-65)$. Rubinstein and van Tulder (66) also provided a best-evidence review of diagnostic procedures for neck and low back pain. They commented that it is quite remarkable that while many named orthopedic tests of the neck and low back are often illustrated in orthopedic textbooks, there is little evidence to support their diagnostic accuracy, and therefore their use in clinical practice. Consistent with clinical experience, many studies have demonstrated that the physical examination serves primarily to confirm suspicions raised during the history. The placebo controlled technique is considered the gold standard, but has limited clinical utility due to ethical and cost implications. Controlled comparative blocks with short and long acting local anesthetics are an acceptable alternative strategy (1-3,67-70).

Controlled comparative blocks have been criticized and the accuracy and validity of these precision diagnostic techniques have been questioned (71-79). Although these tests control and verify for location of local anesthetic delivery, they are faulted for assuming that the report and documentation of the magnitude and quality of pain relief are accurate. Because these tests employ subjective criteria, i.e., rely on a patient's report of presence or absence of pain following a block and ability to isolate different painful areas, or differentiate between significant and insignificant pain relief (when pain relief is incomplete), they promote doubt about the accuracy of these procedures.

Three systematic reviews have concluded the evidence for diagnostic accuracy of lumbar facet joint nerve blocks as strong (1-3). Further, Rubinstein and van Tulder (66) concluded that there is strong evidence for the diagnostic accuracy of facet joint blocks in evaluating spinal pain. 
Facet joint pain may be managed by intraarticular injections, facet joint nerve blocks, and neurolysis of facet joint nerves. However, conflicting results have been reported for the value of the different treatment modalities in systematic reviews $(5,6,80-86)$. A narrative review by Bogduk (87) suggested that intraarticular facet joint injections were no better than placebo for chronic lumbar spine pain. Boswell et al $(5,6)$, in systematic reviews of therapeutic facet joint interventions, showed moderate evidence for lumbar intraarticular facet joint injections for short-term improvement, but only limited evidence for long-term improvement. Geurts et al (80) concluded that there was moderate evidence that radiofrequency lumbar facet denervation was more effective for chronic low back pain than placebo, and there was only limited evidence for effectiveness of radiofrequency neurotomy for chronic cervical zygapophysial joint pain after flexion/extension injury. However, Geurts et al (80) included both medial branch neurotomy and intraarticular neurotomy in their evaluation, along with dorsal root denervation. Manchikanti et al (83) evaluated medial branch neurotomy for the management of chronic spinal pain utilizing randomized and observational reports, and concluded that there was strong evidence for short-term relief and moderate evidence for long-term relief of facet joint pain.

This systematic review is undertaken to determine the accuracy of lumbar facet joint blocks in the diagnosis of chronic low back pain and to evaluate the effectiveness of therapeutic facet joint interventions in the treatment of chronic low back pain of lumbar facet joint origin.

\section{Methods}

\section{Literature Search}

A comprehensive literature search was conducted including Medline and EMBASE from 1966 through December 2008, Cochrane database, Clinical Trial Registry, systematic reviews, narrative reviews, and crossreferences to the reviews published in the English language.

The search strategy consisted of chronic low back pain, facet or zygapophysial joint pain, lumbar facet injections, lumbar facet joint nerve blocks, intraarticular lumbar facet injections, and lumbar radiofrequency neurotomy.

\section{Diagnostic Lumbar Facet Joint Interventions}

\section{Selection Criteria}

All studies published on the diagnosis of lumbar facet joint pain in patients with chronic pain of greater than 3 months duration were included for review. Only the studies utilizing controlled diagnostic blocks either placebo or comparative local anesthetic blocks under fluoroscopy were included. The criterion standard for diagnosis of lumbar facet joint pain was at least $80 \%$ pain relief for the duration of local anesthetic and ability to perform previously painful movements.

All non-clinical studies were excluded. Further, case reports, book chapters, non-evidence-based guidelines, letters, and expert opinions were excluded.

\section{Review Criteria}

The manuscripts meeting the inclusion criteria of $80 \%$ relief with ability to perform previously painful maneuvers were included in methodologic quality assessment. Two physician reviewers evaluated and graded articles meeting inclusion criteria for methodologic quality and grading of evidence as described by the Agency for Healthcare Research and Quality (AHRQ) for diagnostic studies (88) and any disagreements were resolved by the third physician. Consensus-based weighted scoring developed by the guidelines committee of the American Society of Interventional Pain Physicians (ASIPP) was utilized, which was refined and used in other evaluations $(85,86,89-94)$.

The quality of individual articles was evaluated using the above criteria with application of weighted scores. For inclusion in the analysis, each study should have scored at least 50 on a scale of 0 to 100 .

If there was a conflict of interest with the reviewed manuscripts with authorship or any other type of conflict, the involved authors did not review the manuscripts for quality assessment, clinical relevance, evidence synthesis, or grading of evidence.

\section{Level of Evidence}

There is no hierarchy of evidence described for diagnostic studies grading and quality assessment as for therapeutic interventions. Thus, almost all diagnostic accuracy studies are observational. Thus, modified quality of evidence developed by the U.S. Preventive Services Task Force (USPSTF) as illustrated in Table 1 was utilized (95). 
Table 1. Modified quality of evidence developed by USPSTF.

\begin{tabular}{|c|l||}
\hline \hline I: & Evidence obtained from multiple properly conducted diagnostic accuracy studies. \\
\hline II-I: & Evidence obtained from at least one properly conducted diagnostic accuracy study of adequate size. \\
\hline II-2: & Evidence obtained from at least one properly designed small diagnostic accuracy study. \\
\hline II-3: & Evidence obtained from diagnostic studies of uncertainty. \\
\hline III: & Opinions of respected authorities, based on clinical experience descriptive studies and case reports or reports of expert committees. \\
\hline \hline
\end{tabular}

Adapted and modified from the U.S. Preventive Services Task Force (USPSTF) (95).

\section{Therapeutic Facet Joint Interventions}

\section{Inclusion Criteria}

Three types of facet joint interventions were included in this review: intraarticular facet joint injections, facet joint nerve blocks, and medial branch radiofrequency neurotomy. All studies must have provided appropriate management with outcome evaluations of at least 6 months and appropriate statistical analysis. Studies should also have met diagnostic criteria with controlled (placebo or dual) diagnostic blocks with at least $80 \%$ relief.

Reports without appropriate diagnosis and elimination of false-positive responses, non-systematic reviews, book chapters, and case reports were excluded.

\section{Outcome Parameters}

The primary outcome measure was pain relief (short-term relief up to 6 months and long-term relief greater than 6 months) at various time points reported at least over a period of 6 months. The secondary outcome measures were functional status improvement, psychological status improvement, return to work, and opioid intake.

\section{Methodologic Quality Assessment}

The quality of each individual article used in this analysis was assessed by modified Cochrane review criteria with weighted scores (96) for randomized trials and AHRQ quality criteria for assessment of observational studies (88) with weighted scoring, as developed by ASIPP (85) and utilized in multiple other systematic reviews $(86,92,97-105)$.

Only the studies scoring at least 50 of 100 on weighted scoring criteria were utilized for analysis.

Each study was evaluated by 2 physicians for stated criteria and any disagreements were resolved by the third physician. If there was a conflict of interest with the reviewed manuscripts with authorship or any other type of conflict, the involved authors did not review the manuscripts for quality assessment, clinical relevance, evidence synthesis, or grading of evidence.

If there were 4 randomized trials evaluating any one of the techniques - namely intraarticular injections - facet joint nerve blocks, or radiofrequency neurotomy, observational studies were not included in the methodologic quality assessment as well as the evidence synthesis.

\section{Clinical Relevance}

Clinical relevance of the included randomized trials was evaluated according to 5 questions recommended by the Cochrane Back Review Group $(82,106)$. Each question was scored positive $(+)$ if the clinical relevance item was met, negative $(-)$ if the item was not met, and unclear (?) if data were not available to answer the question.

In the updated Cochrane review of "Injection Therapy for Subacute and Chronic Low Back Pain" (82) the authors considered a $20 \%$ improvement in pain scores (107) and a 10\% improvement in functioning outcomes (108) to be clinically important. This review utilized stricter criteria than previous systematic reviews. Any relief of 6 months or less was considered as short-term, whereas Cochrane reviews (82) and others (5-7) have considered 6 weeks as short-term and longer than 6 weeks as long-term. We also utilized methodologic quality assessment criteria for minimum inclusion, thus this systematic review is expected to provide robust results, and the inclusion of observational studies is expected to improve the generalizability of the systematic review (109-113).

\section{Analysis of Evidence}

Analysis was conducted using 5 levels of evidence, ranging from Level I to III, with 3 subcategories in Level II developed by the USPSTF (95). 


\section{Recommendations}

Grading recommendations were based on Guyatt et al's criteria with 6 Levels, 1A - 1C/strong and 2A - 2C/weak as illustrated in Table 2 (114).

\section{Outcome of the Studies}

A study was judged to be positive if the therapeutic facet joint interventions were clinically relevant and effective, either with a placebo control or active control in randomized trials. This indicates that the difference in the effect for the primary outcome measure was statistically significant on the conventional $5 \%$ level. In a negative study, no difference between the study treatments or no improvement from baseline was found. Further, the outcomes were judged at the reference point with positive or negative results reported at 3 months, 6 months, and one year. For observational studies, a study was judged to be positive if the authors concluded that the therapeutic facet joint interventions were effective, with outcomes reported at the reference point with positive or negative results at 3 months, 6 months, and one year.

\section{Results}

\section{Diagnostic Lumbar Facet Joint Nerve Blocks}

Our comprehensive search yielded 1,782 articles (Fig. 1). Of these, 74 full manuscripts were reviewed, whereas 35 manuscripts were considered for inclusion $(31,32,36-38,46,48-65,76,115-124)$. Other manuscripts described pain patterns, nerve supply, and therapeutic interventions.

\section{Methodologic Quality Assessment}

A total of 7 studies met the inclusion criteria for methodologic assessment utilizing controlled local anesthetic blocks with evaluation of at least $80 \%$ pain relief and ability to perform multiple maneuvers $(38,56-58,60,62,65), 7$ studies were excluded as they evaluated with only single block (48-50,52-55), 14 studies were excluded as the inclusion criteria was the relief of pain less than $80 \%(31,32,36,37,46,51,59,61,76$, $116-118,122,123), 3$ studies $(63,64,124)$ were excluded as these were subgroup analysis of other studies, one study (121) evaluated validity of diagnosis with a 2-

Table 2. Grading recommendations.

\begin{tabular}{|c|c|c|c|}
\hline $\begin{array}{l}\text { Grade of Recommendation/ } \\
\text { Description }\end{array}$ & $\begin{array}{l}\text { Benefit vs Risk and } \\
\text { Burdens }\end{array}$ & $\begin{array}{l}\text { Methodological Quality of } \\
\text { Supporting Evidence }\end{array}$ & Implications \\
\hline $\begin{array}{l}\text { 1A/strong recommendation, } \\
\text { high-quality evidence }\end{array}$ & $\begin{array}{l}\text { Benefits clearly outweigh } \\
\text { risk and burdens, or vice } \\
\text { versa }\end{array}$ & $\begin{array}{l}\text { RCTs without important limitations } \\
\text { or overwhelming evidence from } \\
\text { observational studies }\end{array}$ & $\begin{array}{l}\text { Strong recommendation, can apply } \\
\text { to most patients in most circum- } \\
\text { stances without reservation }\end{array}$ \\
\hline $\begin{array}{l}\text { 1B/strong recommendation, } \\
\text { moderate quality evidence }\end{array}$ & $\begin{array}{l}\text { Benefits clearly outweigh } \\
\text { risk and burdens, or vice } \\
\text { versa }\end{array}$ & $\begin{array}{l}\text { RCTs with important limitations } \\
\text { (inconsistent results, methodologi- } \\
\text { cal flaws, indirect, or imprecise) or } \\
\text { exceptionally strong evidence from } \\
\text { observational studies }\end{array}$ & $\begin{array}{l}\text { Strong recommendation, can apply } \\
\text { to most patients in most circum- } \\
\text { stances without reservation }\end{array}$ \\
\hline $\begin{array}{l}1 \mathrm{C} / \text { strong recommendation, } \\
\text { low-quality or very low-quality } \\
\text { evidence }\end{array}$ & $\begin{array}{l}\text { Benefits clearly outweigh } \\
\text { risk and burdens, or vice } \\
\text { versa }\end{array}$ & Observational studies or case series & $\begin{array}{l}\text { Strong recommendation but may } \\
\text { change when higher quality evi- } \\
\text { dence becomes available }\end{array}$ \\
\hline $\begin{array}{l}\text { 2A/weak recommendation, high- } \\
\text { quality evidence }\end{array}$ & $\begin{array}{l}\text { Benefits closely balanced } \\
\text { with risks and burden }\end{array}$ & $\begin{array}{l}\text { RCTs without important limitations } \\
\text { or overwhelming evidence from } \\
\text { observational studies }\end{array}$ & $\begin{array}{l}\text { Weak recommendation, best action } \\
\text { may differ depending on circum- } \\
\text { stances or patients' or societal } \\
\text { values }\end{array}$ \\
\hline $\begin{array}{l}\text { 2B/weak recommendation, } \\
\text { moderate-quality evidence }\end{array}$ & $\begin{array}{l}\text { Benefits closely balanced } \\
\text { with risks and burden }\end{array}$ & $\begin{array}{l}\text { RCTs with important limitations } \\
\text { (inconsistent results, methodologi- } \\
\text { cal flaws, indirect, or imprecise) or } \\
\text { exceptionally strong evidence from } \\
\text { observational studies }\end{array}$ & $\begin{array}{l}\text { Weak recommendation, best action } \\
\text { may differ depending on circum- } \\
\text { stances or patients' or societal } \\
\text { values }\end{array}$ \\
\hline $\begin{array}{l}\text { 2C/weak recommendation, } \\
\text { low-quality or very low-quality } \\
\text { evidence }\end{array}$ & $\begin{array}{l}\text { Uncertainty in the estimates } \\
\text { of benefits, risks, and burden; } \\
\text { benefits, risk, and burden } \\
\text { may be closely balanced }\end{array}$ & Observational studies or case series & $\begin{array}{l}\text { Very weak recommendations; } \\
\text { other alternatives may be equally } \\
\text { reasonable }\end{array}$ \\
\hline
\end{tabular}

Adapted from Guyatt $\mathrm{G}$ et al. Grading strength of recommendations and quality of evidence in clinical guidelines. Report from an American College of Chest Physicians task force. Chest 2006; 129:174-181 (114). 


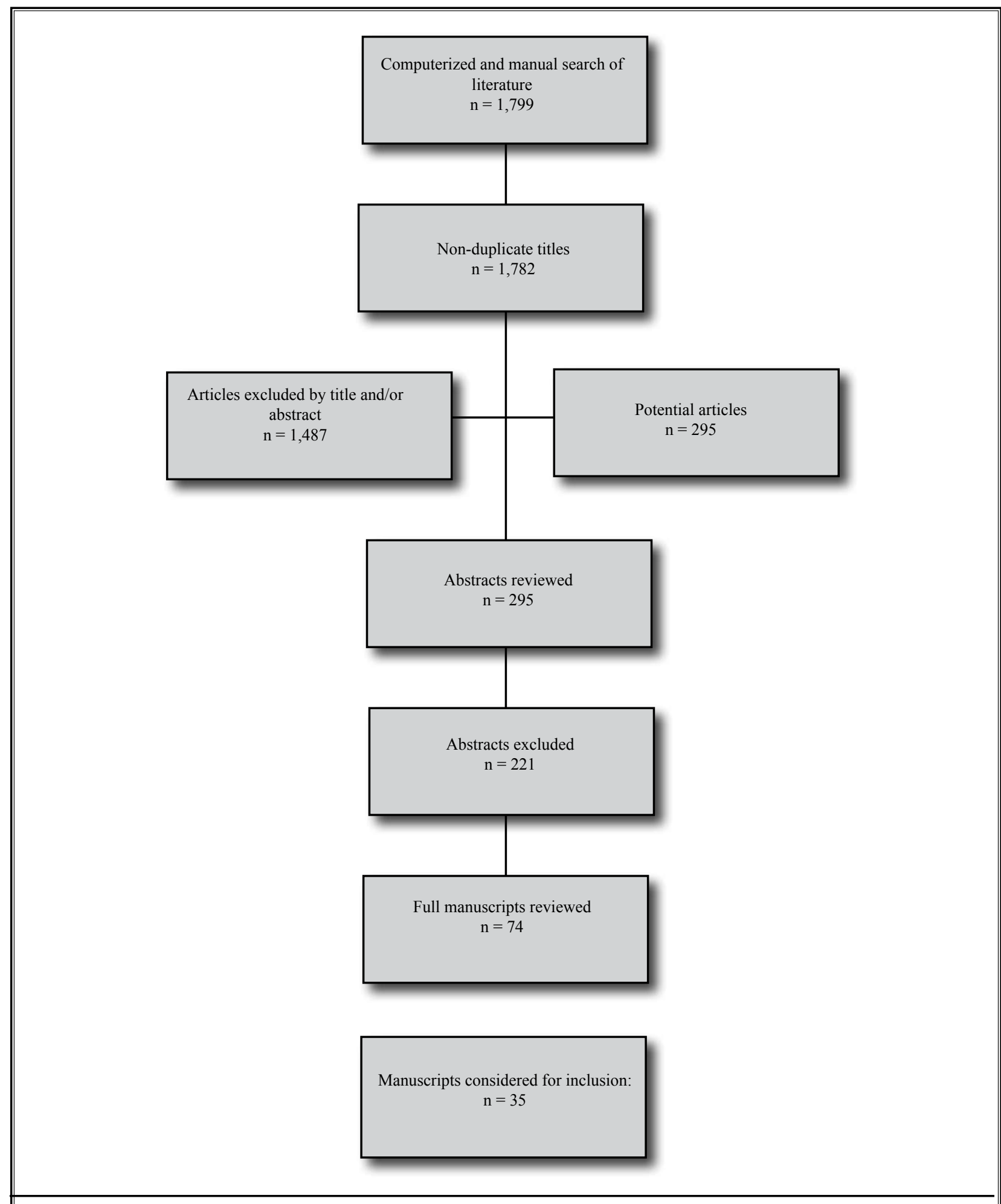

Fig. 1. The flow diagram for diagnostic studies. 
year follow-up, 2 studies $(119,120)$ evaluated the effect of sedation, and another study (115) evaluated the role of psychological factors.

Methodologic quality assessment is illustrated in Table 3. The data and prevalence of the 7 included studies are illustrated in Table 4.

Manchikanti and coauthors in multiple publications $(57,58,60)$ evaluated prevalence and false-positive rates of diagnostic blocks. In all included studies they utilized a criterion standard of $80 \%$ pain relief with the ability to perform previously painful movements without pain utilizing $1 \%$ lidocaine. In a large study of 500 patients in which prevalence of facet joint pain in chronic spinal pain of cervical, thoracic, and lumbar regions were evaluated (58), 397 patients were evaluated for low back pain showing a prevalence of $31 \%(95 \% \mathrm{Cl}, 27 \%, 36 \%)$ with a false-positive rate with single blocks with lidocaine of $27 \%(95 \% \mathrm{Cl}$, $22 \%, 32 \%)$. The second large study by Manchukonda et al (60) evaluated 438 patients with 303 patients with lumbar pain. Prevalence of lumbar facet joint pain was determined as $27 \%(95 \% \mathrm{Cl}, 22 \%, 33 \%)$, with a falsepositive rate of single blocks in the lumbar region of $45 \%$ (95\% Cl, 36\%, 53\%).

Schwarzer et al (38) determined the prevalence of pain arising from the zygapophysial joint in patients with chronic low back pain and to determine whether any clinical features could distinguish patients with and without such pain. The results showed 20 patients $32 \%(95 \% \mathrm{Cl} ; 20 \%$ to $44 \%)$ obtained greater than $50 \%$ relief of their pain following the administration of saline. Fifty seven patients completed the study; 23 of them $37 \%$ (95\% Cl; $25 \%$ to $49 \%$ ) failed to obtain relief following the injection of saline but obtained relief following one or more intraarticular injections of local anaesthetic. None of the historical features or clinical tests could discriminate those patients with and those without zygapophysial joint pain.

Manchikanti et al (62) in an evaluation of the relative contributions of various structures in chronic low back pain evaluated 120 patients with a chief complaint of low back pain who were evaluated with facet joint

Table 3. Methodological quality assessment and scoring of lumbar diagnostic facet joint nerve block studies.

\begin{tabular}{|c|c|c|c|c|c|c|c|c|}
\hline \multirow[b]{2}{*}{ STUDY } & \multirow[b]{2}{*}{$\begin{array}{c}\text { Study } \\
\text { Population } \\
\text { (15) }\end{array}$} & \multirow[b]{2}{*}{$\begin{array}{c}\text { Adequate } \\
\text { Description } \\
\text { of Test (10) }\end{array}$} & \multicolumn{2}{|c|}{$\begin{array}{c}\text { Appropriate Reference } \\
\text { Standard (30) }\end{array}$} & \multicolumn{2}{|c|}{$\begin{array}{c}\text { Blinded Comparison of Test } \\
\text { (30) }\end{array}$} & \multirow[b]{2}{*}{$\begin{array}{c}\begin{array}{c}\text { Avoidance } \\
\text { of } \\
\text { Verification }\end{array} \\
\text { Bias (15) }\end{array}$} & \multirow[b]{2}{*}{$\begin{array}{c}\text { TOTAL } \\
\text { (100) }\end{array}$} \\
\hline & & & $\begin{array}{c}\text { Appropriate } \\
\text { reference } \\
\text { standard (gold } \\
\text { standard) used } \\
\text { for comparison } \\
\text { (15) }\end{array}$ & $\begin{array}{c}\text { Reference } \\
\text { standard } \\
\text { reproducible } \\
\text { (15) }\end{array}$ & $\begin{array}{c}\text { Evaluation } \\
\text { of test } \\
\text { without } \\
\text { knowledge } \\
\text { of disease } \\
\text { status, if } \\
\text { possible (15) }\end{array}$ & $\begin{array}{l}\text { Independent, } \\
\text { blind } \\
\text { interpretation } \\
\text { of test and } \\
\text { reference } \\
\text { (15) }\end{array}$ & & \\
\hline $\begin{array}{l}\text { Manchikanti et } \\
\text { al } 2002 \text { (57) }\end{array}$ & 15 & 10 & 10 & 15 & - & 10 & 15 & 75 \\
\hline $\begin{array}{l}\text { Manchikanti et } \\
\text { al } 2004 \text { (58) }\end{array}$ & 15 & 10 & 10 & 15 & - & 10 & 15 & 75 \\
\hline $\begin{array}{l}\text { Manchukonda } \\
\text { et al } 2007(60)\end{array}$ & 15 & 10 & 10 & 15 & - & 10 & 15 & 75 \\
\hline $\begin{array}{l}\text { Schwarzer et al } \\
1995(38)\end{array}$ & 15 & 10 & 10 & 15 & - & 10 & 15 & 75 \\
\hline $\begin{array}{l}\text { Manchikanti et } \\
\text { al } 2001(62)\end{array}$ & 15 & 10 & 10 & 15 & - & 10 & 15 & 75 \\
\hline $\begin{array}{l}\text { Manchikanti et } \\
\text { al } 2003 \text { (56) }\end{array}$ & 15 & 10 & 10 & 15 & - & 10 & 15 & 75 \\
\hline $\begin{array}{l}\text { Manchikanti et } \\
\text { al } 2007 \text { (65) }\end{array}$ & 15 & 10 & 10 & 10 & - & 10 & 15 & 75 \\
\hline
\end{tabular}

Adapted and modified from West S et al. Systems to Rate the Strength of Scientific Evidence, Evidence Report, Technology Assessment No. 47. AHRQ Publication No. 02-E016 (88). 
Pain Physician: March/April 2009:12:437-460

Table 4. Data of prevalence with controlled diagnostic blocks and false-positive rates in lumbar region.

\begin{tabular}{|c|c|c|c|c|}
\hline Study & $\begin{array}{l}\text { Methodological } \\
\text { Criteria }\end{array}$ & Participants & Prevalence & False-Positive Rate \\
\hline Manchikanti et al 2002 (57) & 75 & 120 & $40 \%$ (95\% CI; 31\%-49\%) & $30 \%(95 \%$ CI; $20 \%-40 \%)$ \\
\hline Manchikanti et al 2004 (58) & 75 & 397 & $31 \%(95 \%$ CI; $27 \%-36 \%)$ & $27 \%(95 \%$ CI; $22 \%-32 \%)$ \\
\hline Manchukonda et al 2007 (60) & 75 & 303 & $27 \%$ (95\% CI; $22 \%-33 \%)$ & $45 \%$ (95\% CI; 36\%-53\%) \\
\hline Schwarzer et al 1995 (38) & 75 & 63 & $37 \%$ (95\% CI; 25\%-49\%) & NA \\
\hline Manchikanti et al 2001 (62) & 75 & 120 & $40 \%$ (95\% CI; 31\%-49\%) & $47 \%$ (95\% CI; 35\%-59\%) \\
\hline Manchikanti et al 2003 (56) & 75 & 300 & $\begin{array}{l}\text { I. } 21 \%(95 \% \text { CI; } 14 \%-27 \%) \\
\text { II. } 41 \%(95 \% \text { CI; } 33 \%-49 \%)\end{array}$ & $\begin{array}{l}\text { I. } 17 \%(95 \% \text { CI; } 10 \%-24 \%) \\
\text { II. } 27 \%(95 \% \text { CI; } 18 \%-36 \%)\end{array}$ \\
\hline Manchikanti et al 2007 (65) & 75 & 117 & $16 \%$ (95\% CI; 9\%-23\%) & $49 \%(95 \%$ CI; 39\%-59\%) \\
\hline Overall & & 1,420 & $31 \%(95 \% \mathrm{CI} ; 28 \%-33 \%)$ & $30 \%^{*}(95 \% \mathrm{CI} ; 27 \%-33 \%)$ \\
\hline
\end{tabular}

$\mathrm{CI}=$ confidence interval; NA =not available; \# Schwarzer et al (38) not included

nerve blocks, provocative discography, and sacroiliac joint injections. The results of this study showed that the facet joint is the most common pain generator in chronic low back pain with identification of the facet joint in $40 \%(95 \% \mathrm{CL}, 31 \%, 49 \%)$ of patients, followed by the disc in $26 \%(95 \% \mathrm{CL}, 18 \%, 34 \%)$ of patients, and the sacroiliac joint in only $2 \%$ of the patients.

Manchikanti et al (56) evaluated chronic low back pain of facet joint origin based on involvement of single or multiple spinal regions. The concluded that the prevalence of lumbar facet joint pain in patients with low back only was $21 \%(95 \% \mathrm{Cl}, 14 \%, 27 \%)$, compared to $41 \%(95 \% \mathrm{Cl}, 33 \%, 49 \%)$ of the patients with low back pain with involvement of other regions of the spine with controlled comparative local anesthetic blocks. A false-positive rate of $17 \%(95 \% \mathrm{Cl}, 10 \%$, $24 \%$ ) in patients with low back pain only and $27 \%$ $(95 \% \mathrm{Cl}, 18 \%, 36 \%)$ in patients with involvement of multiple regions of the spine was demonstrated with single blocks.

\section{Diagnostic Accuracy}

The accuracy was evaluated in 7 studies illustrating either prevalence or false-positive rates (Table 4). A total of 1,320 patients were studied for diagnostic accuracy. The overall prevalence has been demonstrated as $27 \%$ to $40 \%$ with $16 \%$ in postlumbar laminectomy patients. The recent study (60) with large population of 303 showed a prevalence of $27 \%$ with confidence intervals ranging from $29 \%$ to $22 \%$ to $33 \%$.

\section{Prevalence}

The prevalence of lumbar facet joint pain based on the controlled diagnostic blocks is shown to be $21 \%$ to $41 \%(95 \% \mathrm{Cl}, 14 \%$ to $53 \%)$ with overall prevalence of $31 \%(95 \% \mathrm{Cl} 28 \%-33 \%)$

\section{False-Positive Rates}

False-positive rates of $17 \%$ to $49 \%$ were demonstrated with Cls ranging from $10 \%$ to $59 \%$ with overall false-positive rate of $30 \%(95 \% \mathrm{Cl} 27 \%-33 \%)$.

\section{Confounding Factors}

Sedation as a confounding factor was evaluated in the lumbar spine. Studies by Manchikanti et al $(118,119)$ have demonstrated that conscious sedation may provide that $5 \%$ of subjects in the placebo group and up to $10 \%$ of subjects in the active group reported $\geq 80 \%$ pain relief and were able to perform movements that were painful prior to the administration of the intravenous agents. Application of the $\geq 80 \%$ pain reduction criterion standard instead of $\leq 50 \%$ pain reduction decreased the false-positive response from $15 \%$ to $10 \%$. A systematic review by Smith et al (94) showed no significant evidence of the influence of sedation either with midazolam or fentanyl in the evaluation of cervical and lumbar facet joint pain with controlled cervical and lumbar facet joint nerve blocks with an indicated evidence of Level II-1, with application of stringent criteria of at least $80 \%$ pain relief and the ability to perform previously painful movements after the diagnostic blocks. 
Influence of psychological factors was also evaluated $(64,115)$. The evaluation by Manchikanti et al (64) showed no significant differences among patients either in terms of prevalence or false-positive rates or prevalence in the diagnosis of lumbar facet joint pain. The prevalence of facet joint pain was seen in $25 \%$ of the patients with no psychopathology with a $50 \%$ false-positive rate, whereas in patients with major depression, it was $31 \%$, with generalized anxiety disorder, $28 \%$, and in patients with somatization disorder, prevalence was $32 \%$, and false-positive rates were $38 \%, 43 \%$, and $39 \%$ respectively.

Age as a confounding factor was evaluated. Manchikanti et al (63) showed variable prevalence of facet joint involvement in lumbar spine ranging from $18 \%$ to $44 \%$, with significant differences noted among some groups. The results showed in Group I (18 to 30 years), the prevalence was $28 \%$ with falsepositive rates of $40 \%$; in Group II (31 to 40 years), the prevalence was $18 \%$ with false-positive rates of $50 \%$; in Group III (41 to 50 years), the prevalence was $28 \%$ with false-positive rates of $45 \%$; in Group IV (51 to 60 years), the prevalence was $44 \%$ with false-positive rates of $30 \%$; in Group V (61 to 70 years), the prevalence was $21 \%$ with false-positive rates of $64 \%$; and in Group VI (over 70 years), the prevalence was $26 \%$ with false-positive rates of $43 \%$. Thus, the highest prevalence was seen in patients aged 51 to 60 years, whereas the lowest was seen in the age group of 31 to 40 years with $18 \%$. Manchikanti et al (65) also showed significantly less proportion of patients with facet joint pain after lumbar surgery and occupational injury (124) with no differences based on obesity (59), based on gender, or smoking status (124).

\section{Criterion Standard}

No tissue diagnosis (biopsy or autopsy) techniques are available to diagnose facet joint pain and confirm specificity and sensitivity of facet joint nerve blocks. However, pain relief and stability of the diagnosis with long-term follow-up are employed as the criterion standards and are accepted across different medical disciplines $(1-3,74,121)$.

\section{Validity}

Controlled lumbar facet joint nerve blocks have been established as a method to diagnose lumbar facet joint pain, either with placebo control or controlled comparative local anesthetic blocks that meet specific criteria of pain relief and functional improvement (1-
3,33,36-38,46,47,51,56-66). Pain relief (74) and longterm follow-up are employed as the criterion standards and are accepted across different medical disciplines $(74,110,121)$. Long-term relief of lumbar facet joint interventions has been demonstrated $(4-7,83,85,121)$.

\section{Study Designs}

All the studies included in the methodologic quality assessment met inclusion criteria as well as study design criteria. There has been significant controversy over the study designs with some reviewers calling for randomized controlled trials (RCTs) for diagnostic interventions $(6,80)$. However, the design accuracy of diagnostic studies involves consecutive or non-consecutive allocation and observational studies (85).

\section{Level of Evidence}

The level of evidence was Level I or Level II-1 evidence based on the 7 included studies.

\section{Therapeutic Facet Joint Interventions}

A comprehensive literature search was performed for lumbar intraarticular facet joint injections, lumbar facet joint nerve blocks, and lumbar facet joint nerve radiofrequency neurotomy (Fig. 2). The entire search yielded a total of 40 studies relevant to therapeutic lumbar facet interventions $(37,47,117,121,123,125-159)$.

\section{Randomized Trials}

\section{Methodologic Quality Assessment}

Of the 6 randomized trials identified evaluating the effectiveness of lumbar intraarticular facet joint injections (132-137), 5 studies failed to meet inclusion criteria for methodologic quality assessment due to lack of controlled diagnostic blocks (132-136), whereas one study (137) evaluated the injections of carpometacarpal (CMC) joints of the thumb.

There were 7 studies evaluating therapeutic lumbar facet joint nerve blocks $(37,121,135,136,139-141)$. Of these, one study (37) evaluated only diagnostic interventions. Another study (121) evaluated diagnostic validity of lumbar facet joint nerve blocks. Two studies $(135,136)$ had only short-term evaluation without diagnostic blocks. One study (139) was a preliminary report of the one-year report (140). Consequently 2 studies met inclusion criteria $(140,141)$.

There were 7 studies evaluating radiofrequency neurotomy of lumbar facet joint nerves (142$144,147,148,150,155)$. Of these, only one study met 


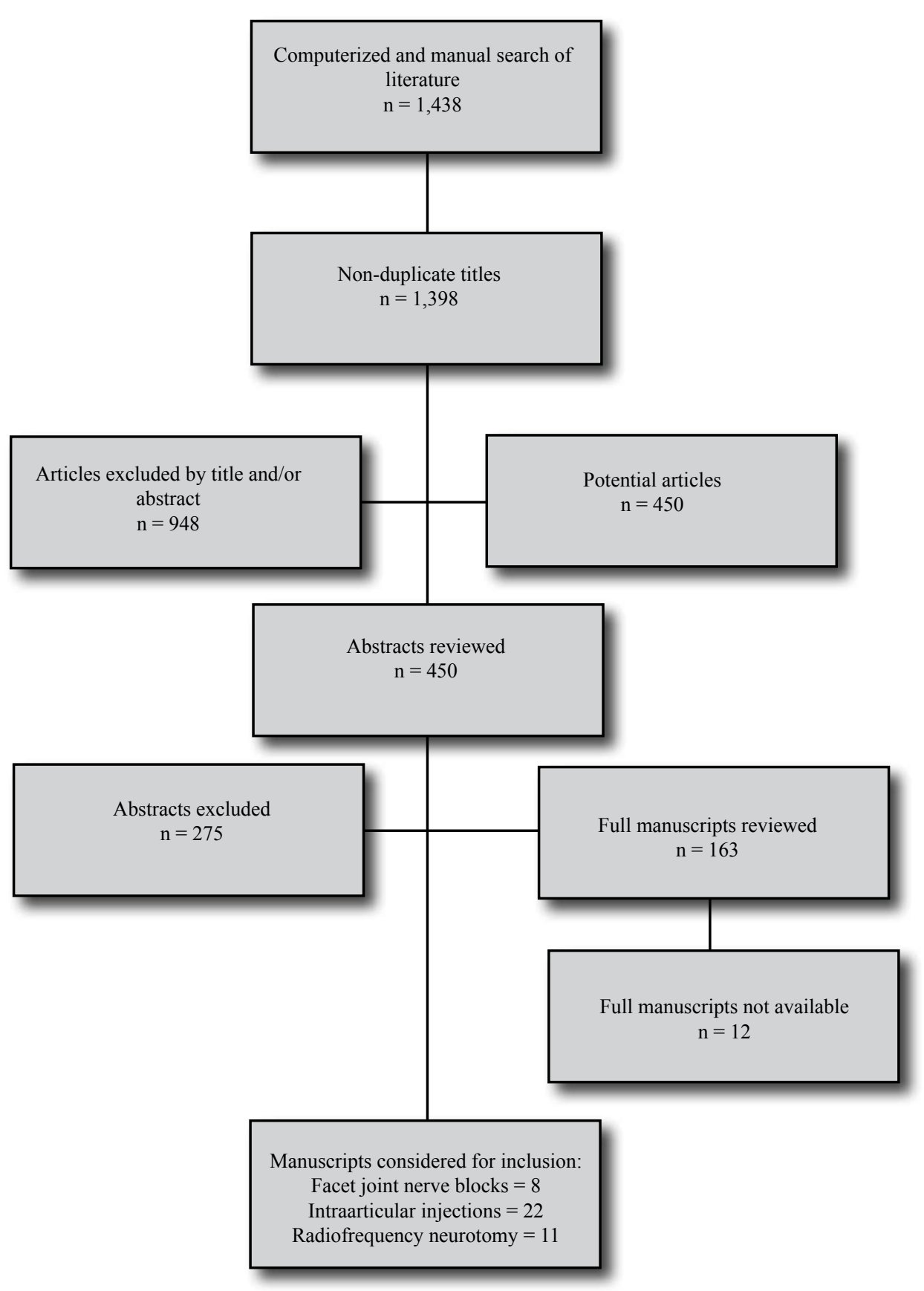

Fig. 2. The flow diagram illustrating published literature evaluating therapeutic lumbar facet joint interventions.

the inclusion criteria (142). van Wijk et al (143), Leclaire et al (144), Gallagher et al (147), van Kleef et al (150), and Tekin et al (155) were excluded due to lack of controlled diagnostic blocks. One study (148) was excluded as it evaluated intraarticular facet joint denervation, which is not medial branch neurotomy, with lack of appropriate diagnostic criteria.

Table 5 illustrates the methodologic quality assessment of randomized clinical trials evaluating the 
Table 5. Methodological quality assessment of randomized clinical trials of therapeutic lumbar facet joint interventions.

\begin{tabular}{|c|c|c|c|c|c|}
\hline \multicolumn{2}{|c|}{ CRITERION } & $\begin{array}{c}\text { Weighted } \\
\text { Score } \\
\text { (points) } \\
\end{array}$ & $\begin{array}{l}\text { Manchikanti et } \\
\quad \text { al (141) }\end{array}$ & $\begin{array}{l}\text { Manchikanti et al } \\
\qquad(\mathbf{1 4 0 )}\end{array}$ & $\begin{array}{l}\text { Nath et al } \\
\quad(\mathbf{1 4 2})\end{array}$ \\
\hline \multicolumn{2}{|c|}{ 1. Study population } & 35 & 14 & 23 & 8 \\
\hline A & Homogeneity & 2 & 2 & 2 & 2 \\
\hline B & Comparability of relevant baseline characteristics & 5 & 5 & 2 & 2 \\
\hline $\mathrm{C}$ & Randomization procedure adequate & 4 & 2 & 4 & 4 \\
\hline $\mathrm{D}$ & Drop-outs described for each study group separately & 3 & 3 & 3 & - \\
\hline \multirow[t]{2}{*}{ E } & $<20 \%$ loss for follow-up & 2 & 2 & 2 & - \\
\hline & $<10 \%$ loss for follow-up & 2 & - & 2 & - \\
\hline \multirow[t]{2}{*}{$\mathrm{F}$} & $>50$ subject in the smallest group & 8 & - & 8 & - \\
\hline & $>100$ subjects in the smallest group & 9 & - & - & - \\
\hline \multicolumn{2}{|c|}{ 2. Interventions } & 25 & 20 & 15 & 20 \\
\hline G & Interventions included in protocol and described & 10 & 10 & 10 & 10 \\
\hline $\mathrm{H}$ & Pragmatic study & 5 & 5 & 5 & - \\
\hline I & Co-interventions avoided or similar & 5 & 5 & - & 5 \\
\hline $\mathrm{J}$ & Placebo-controlled & 5 & - & - & 5 \\
\hline \multicolumn{2}{|c|}{ 3. Effect } & 30 & 20 & 20 & 17 \\
\hline $\mathrm{K}$ & Patients blinded & 5 & - & 5 & 5 \\
\hline $\mathrm{L}$ & Outcome measures relevant & 10 & 10 & 10 & 10 \\
\hline M & Blinded outcome assessments & 10 & 5 & 5 & - \\
\hline $\mathrm{N}$ & Follow-up period adequate & 5 & 5 & 5 & 2 \\
\hline \multicolumn{2}{|c|}{ 4. Data-presentation and analysis } & 10 & 5 & 10 & 5 \\
\hline $\mathrm{O}$ & Intention-to-treat analysis & 5 & - & 5 & - \\
\hline $\mathrm{P}$ & $\begin{array}{l}\text { Frequencies of most important outcomes presented for } \\
\text { each treatment group }\end{array}$ & 5 & 5 & 5 & 5 \\
\hline \multicolumn{2}{|r|}{ TOTAL SCORE } & 100 & 59 & 73 & 50 \\
\hline
\end{tabular}

Methodological criteria and scoring adapted from Koes BW et al. Efficacy of epidural steroid injections for low back pain and sciatica: A systematic review of randomized clinical trials. Pain 1995; 63: 279-288 (96).

role of lumbar facet joint interventions. The quality assessment criteria varied from 50 to 73.

\section{Clinical Relevance Assessment}

Table 6 illustrates clinical relevance assessment of 3 randomized trials meeting the inclusion criteria with quality assessment.

\section{Observational Studies}

Multiple observational studies evaluated the role of therapeutic facet joint interventions. Of these, 15 studies evaluated the role of intraarticular injections of lumbar facet joints $(41,117,125-131,137,138,151$ 154). However, none met inclusion criteria.

There was only one study evaluating the role of facet joint nerve blocks compared to intraarticular in- jections (117), which failed to meet inclusion criteria.

There were 8 radiofrequency neurotomy studies $(123,145,146,149,156-159)$. However, only 2 studies $(145,146)$ met inclusion criteria. Two studies $(158,159)$ were excluded as they performed cryoneurotomy. One study (157) was excluded because it included laser denervation. Two studies $(123,156)$ were excluded due to inclusion of only a single block. One study (149) was excluded as it evaluated lesion size.

\section{Methodologic Quality Assessment}

Table 7 illustrates the methodologic quality assessment criteria of observational studies. Both studies met methodologic quality assessment criteria with scores of 73 for the study by Dreyfuss et al (146) and 63 for the study by Gofeld et al (145). 
Pain Physician: March/April 2009:12:437-460

Table 6. Clinical relevance of randomized clinical trials evaluating the effectiveness of lumbar facet joint interventions.

\begin{tabular}{||l|c|c|c||}
\hline & $\begin{array}{c}\text { Manchikanti et al } \\
(\mathbf{1 4 1})\end{array}$ & $\begin{array}{c}\text { Manchikanti et al } \\
\text { (140) }\end{array}$ & $\begin{array}{c}\text { Nath et al } \\
\text { (142) }\end{array}$ \\
\hline $\begin{array}{l}\text { A) Are the patients described in detail so that you can decide whether } \\
\text { they are comparable to those that you see in your practice? }\end{array}$ & + & + & + \\
\hline $\begin{array}{l}\text { B) Are the interventions and treatment settings described well enough so } \\
\text { that you can provide the same for your patients? }\end{array}$ & + & + & + \\
\hline C) Were all clinically relevant outcomes measured and reported? & + & + & + \\
\hline D) Is the size of the effect clinically important? & + & + & + \\
\hline E) Are the likely treatment benefits worth the potential harms? & TOTAL CRITERIA MET & $4 / 5$ & $4 / 5$ \\
\hline
\end{tabular}

+ = positive; - = negative

Scoring adapted from Staal JB et al. Injection therapy for subacute and chronic low back pain: An updated Cochrane review. Spine 2009; 34:49-59 (82).

\section{Intraarticular Facet Joint Blocks}

Of the 5 randomized trials $(132-136)$ and 15 observational studies $(41,117,125-131,137,138,151-154)$, none met inclusion criteria.

\section{Excluded Studies of Intraarticular Injections}

Carette et al (132) failed to exclude placebo responders, which may account for relatively high incidence of patients in their study with presumed facet joint pain. They showed an incidence of $58 \%$ prevalence of facet joint pain based on inclusion criteria of phase 1 of their study. Failure to exclude placebo responders may have diluted the findings of true responses, making detection of differences between the study and the control group difficult. The patients in the methylprednisolone group received a greater proportion of concurrent interventions. At 6 months, $42 \%$ of patients in the steroid group showed benefit compared to $15 \%$ in the sodium chloride solution group. They concluded that there was no significant difference between the two groups. However, the effects and consequences of intraarticular placebo injections of sodium chloride are not known. Normal saline has been shown to provide better pain relief than that expected with a true placebo for a multitude of invasive procedures (160-162).Consequently, even patients with placebo injections of sodium chloride responded to treatment similar to corticosteroid injections. Further, effect of injection of placebo or any other agent in a closed space such as intraarticular injection is not known. The intraarticular injection of sodium chloride solution may produce multiple effects which are not explained at the present time.
Fuchs et al (134) conducted a study comparing intraarticular hyaluronic acid versus glucocorticoid injections for nonradicular pain in the lumbar spine. Sixty patients were included in this randomized, controlled, blind-observer clinical study and randomly assigned to 2 groups to receive $10 \mathrm{mg}$ of sodium hyaluronate or $10 \mathrm{mg}$ of triamcinolone acetonide per facet joint. The facet joints on both sides at levels L5-S1, L5-L4, and L4-L3 were treated once per week under CT guidance. The study visits were timed to permit assessment of the immediate effect as well as possible carryover effects at 3 and 6 months after completion of treatments. Changes in pain were assessed with a visual analogue scale (VAS) and changes in function and quality of life were assessed by the Roland-Morris questionnaire (RMQ), the Oswestry Disability questionnaire (ODQ), the Low Back Outcome Score (LBOS) and the ShortForm 36 (SF-36). Patients reported lasting relief, better function, and improved quality of life with both treatments. The disadvantages of the study include a lack of appropriate diagnosis with controlled diagnostic blocks, thus failing to exclude placebo responders which may have increased the possibility of inclusion of patients without facet joint pain. Furthermore, pain relief of $50 \%$ or greater was achieved only in the triamcinolone group with a reduction of $51.7 \%$ despite a series of injections bilaterally at 3 levels, whereas the reduction was $45.1 \%$ in the sodium hyaluronate group. RMQ scores, ODQ scores, and LBOS showed reduction in sodium hyaluronate of $43.2 \%, 39.1 \%$, and $43.9 \%$ whereas in the triamcinolone group the reduction was $33.4 \%, 29.5 \%$, and $34.8 \%$. Considering that no controlled diagnostic blocks were used, and no 
Table 7. Methodologic quality assessment criteria for observational studies of lumbar facet joint interventions.

\begin{tabular}{|c|c|c|c|}
\hline CRITERION & $\begin{array}{c}\text { Weighted } \\
\text { Score } \\
\text { (points) }\end{array}$ & $\begin{array}{c}\text { Dreyfuss et } \\
\text { al (146) }\end{array}$ & $\begin{array}{c}\text { Gofeld et al } \\
\quad(145)\end{array}$ \\
\hline 1. Study Question & 2 & 2 & 2 \\
\hline - Clearly focused and appropriate question & 2 & & \\
\hline 2. Study Population & 8 & 5 & 5 \\
\hline - Description of study population & 5 & 5 & 5 \\
\hline - Sample size justification & 3 & - & - \\
\hline 3. Comparability of Subjects & 22 & 8 & 8 \\
\hline - Specific inclusion/exclusion criteria for all groups & 5 & 5 & 5 \\
\hline - Criteria applied equally to all groups & 3 & - & - \\
\hline - Comparability of groups at baseline with regard to disease status and prognostic factors & 3 & - & - \\
\hline - Study groups comparable to non-participants with regard to confounding factors & 3 & - & - \\
\hline - Use of concurrent controls & 5 & - & - \\
\hline - Comparability of follow-up among groups at each assessment & 3 & 3 & 3 \\
\hline 4. Exposure or Intervention & 11 & 8 & 8 \\
\hline - Clear definition of exposure & 5 & 5 & 5 \\
\hline - Measurement method standard, valid and reliable & 3 & 3 & 3 \\
\hline - Exposure measured equally in all study groups & 3 & - & - \\
\hline 5. Outcome measures & 20 & 15 & 15 \\
\hline - Primary/secondary outcomes clearly defined & 5 & 5 & 5 \\
\hline - Outcomes assessed blind to exposure or intervention & 5 & - & - \\
\hline - Method of outcome assessment standard, valid and reliable & 5 & 5 & 5 \\
\hline - Length of follow-up adequate for question & 5 & 5 & 5 \\
\hline 6. Statistical Analysis & 19 & 17 & 7 \\
\hline - Statistical tests appropriate & 5 & 5 & - \\
\hline - Multiple comparisons taken into consideration & 3 & 3 & 3 \\
\hline - Modeling and multivariate techniques appropriate & 2 & 2 & - \\
\hline - Power calculation provided & 2 & - & - \\
\hline - Assessment of confounding & 5 & 5 & 2 \\
\hline - Dose-response assessment if appropriate & 2 & 2 & 2 \\
\hline 7. Results & 8 & 8 & 8 \\
\hline - Measure of effect for outcomes and appropriate measure of precision & 5 & 5 & 5 \\
\hline - Adequacy of follow-up for each study group & 3 & 3 & 3 \\
\hline 8. Discussion & 5 & 5 & 5 \\
\hline $\begin{array}{l}\text { - Conclusions supported by results with possible biases and limitations taken into } \\
\text { consideration }\end{array}$ & 5 & 5 & 5 \\
\hline 9. Funding or Sponsorship & 5 & 5 & 5 \\
\hline - Type and sources of support for study & 5 & & \\
\hline TOTAL SCORE $=$ & 100 & 73 & 63 \\
\hline
\end{tabular}

Adapted and modified from West S et al. Systems to Rate the Strength of Scientific Evidence, Evidence Report, Technology Assessment No. 47. AHRQ Publication No. 02-E016 (88). 
mention was made of at least an $80 \%$ relief of pain following a diagnostic block, this study was excluded from the final evaluation.

\section{Level of Evidence}

The evidence based on the present evaluation is Level III or limited.

\section{Recommendations}

Due to lack of significant evidence, the recommendation is that intraarticular injections are $2 \mathrm{C} /$ very weak recommendation or recommendation not to provide intraarticular injections.

\section{Lumbar Facet Joint Nerve Blocks}

Our search strategy included 2 randomized trials of facet joint nerve blocks meeting methodologic assessment criteria $(140,141)$. There were no observational studies meeting inclusion criteria with evaluation of lumbar facet joint nerve blocks.

Manchikanti et al (140) in a randomized, double blind controlled trial evaluated the role of lumbar facet joint nerve blocks in managing chronic facet joint pain. The study was conducted to determine the clinical effectiveness of therapeutic local anesthetic lumbar facet joint nerve blocks with or without steroid in managing chronic function-limiting low back pain of facet joint origin. The study included 60 patients in Group I with local anesthetic and 60 patients in Group II with local anesthetic and steroid. The inclusion criteria were based on the positive response to the diagnostic controlled comparative local anesthetic lumbar facet joint blocks. Outcome measures included numeric pain scores, Oswestry Disability Index (ODI), opioid intake, and work status. All outcome assessments were performed at baseline, 3 months, 6 months, and 12 months. The results showed significant improvement with significant pain relief ( $\geq 50 \%$ ) and functional improvement ( $\geq 40 \%$ ) were observed in $82 \%$ and $85 \%$ in Group I, with significant pain relief in over $82 \%$ of the patients and improvement in functional status in $78 \%$ of the patients. Based on the results of the present study, it appears that patients may experience significant pain relief 44 to 45 weeks of one year, requiring approximately 3 to 4 treatments with an average relief of 15 weeks per episode of treatment. While limitations of this study include a lack of placebo control, the study included an active control in a randomized equivalence or non-inferiority controlled trial, and the study met all the criteria with 60 patients in each group with appropriate outcome measurements.

Manchikanti et al (141) in a randomized clinical trial evaluated 200 patients with controlled diagnostic blocks for the presence of facet joint pain. Eighty-four patients, or $42 \%$ were determined to have lumbar facet joint mediated pain. These patients were randomly allocated into 2 groups: Group I receiving therapeutic injections with local anesthetic and Sarapin, and Group II receiving therapeutic injections with a mixture of local anesthetic, Sarapin, and methylprednisolone. A total of 73 patients were treated with lumbar facet joint nerve blocks under fluoroscopy. Results showed that patients underwent multiple procedures over a period of $2 \frac{1}{2}$ years. The mean number of procedures or interventions was $2.5 \pm 0.09$ from 1 to 3 months, whereas it was $4+/-0.13$ for 4 to 6 months, $6.1 \pm 0.21$ for 7 to 12 months, and $8.4 \pm 0.31$ for 13 to 32 months. Cumulative significant relief with one to 3 injections was $100 \%$ up to 1 to 3 months, $82 \%$ for 4 to 6 months, $21 \%$ for 7 to 12 months, and $10 \%$ after 12 months, with a mean relief of $6.5 \pm 0.76$ months. There was significant improvement noted in overall health status with improvement not only in pain relief, but also with physical, functional, and psychological status, as well as return-to-work status. Even though this is an $\mathrm{RCT}$, it was not blinded. Further, there was no placebo group.

\section{Level of Evidence}

The indicated level of evidence indicated Level II1 or II-2 based on the quality of evidence using the USPSTF criteria (95).

\section{Recommendations}

According to Guyatt et al's criteria (114), the recommendation is strong (1B or 1C) for the use of therapeutic facet joint nerve blocks to provide both shortterm and long-term relief in the treatment of chronic lumbar facet joint pain.

\section{Radiofrequency Neurotomy}

One randomized trial (142) and 2 observational studies $(145,146)$ met inclusion criteria with methodologic quality assessment for evidence synthesis.

Nath et al (142) in a randomized control trial of 40 patients with chronic low back pain (20 active and 20 controls) found that the active treatment group showed improvement accompanied by significantly greater improvements in paravertebral tenderness, 
various movements, quality of life, and use of analgesics. The pain relief was however, only monitored for 6 months, as it was felt that patients who received placebo treatment could not be left untreated for longer than 6 months. Bogduk (163) in a "Point of View" editorial on the Nath et al's study commented that... "Nath et al's study was the first to use controlled diagnostic blocks to select patients, and the first to use correct technique. He did not select ideal patients, free of comorbidity, with already good function, and no depression. He drew his patients from a pain clinic population. This treatment did not relieve every pain that Dr. Nath's patients had. Nevertheless, the index pain was relieved, and corroborated by improvements in function."

Dreyfuss et al (146) reported that $87 \%$ of 15 patients obtained at least $60 \%$ pain relief 12 months status post radiofrequency denervation, with $60 \%$ of the patients achieving at least $90 \%$ relief. In addition to stringent inclusion criteria, the authors used 16 gauge electrodes and assessed the efficacy of radiofrequency denervation by performing electromyography of the multifidus muscle. Another flaw that pervades most radiofrequency studies is that sensory stimulation (usually less than $0.5 \mathrm{~V}$ ) is used to corroborate proximity of the electrode to the targeted medial branch. Whereas sensory stimulation is almost certain to be perceived when the electrode is placed on or adjacent to a neural structure, many patients can perceive concordant sensory stimulation at $0.5 \mathrm{~V}$ or less even when the electrode is purposefully placed in muscle, as during a sham procedure. An attractive alternative to sensory stimulation is to instead attempt to elicit multifidus muscle contraction, as the same medial branch that innervates the facet joint also innervates this paraspinal muscle. In the 2 studies in which the medial branch was identified by motor stimulation of the multifidus muscle, both reported a positive outcome $(146,150)$.

Gofeld et al (145) evaluated in a large clinical audit, extending from 1991 to 2000, 209 patients, with 174 completing the study. They included only the patients with an appropriate response to comparative double diagnostic blocks. Of the 174 patients with complete data, 55 (31.6\%) experienced no benefit from the procedure, 119 patients $(68.4 \%)$ had good to excellent pain relief lasting from 6 to 24 months. They concluded that proper patient selection and anatomically correct radiofrequency denervation of the lumbar zygapophysial joints provides long-term pain relief in a routine clinical setting.

\section{Characteristics of Excluded Studies}

Gallagher et al (147) randomly assigned 41 patients based on their response to diagnostic intraarticular blocks (equivocal or good response) to either sham or true denervation. A statistically significant difference in outcome was observed at one month only between sham and true radiofrequency denervation in those patients who obtained a definitive response to diagnostic blocks. This difference persisted for the duration of the 6 month follow-up.

A prospective, randomized, placebo-controlled double-blind trial ( $n=31$ ) was conducted by van Kleef et al (150) to assess the efficacy of percutaneous radiofrequency denervation of the lumbar facet joints in reducing pain, functional disability, and physical impairment. All patients had chronic back pain for at least one year, suggestive of facet joint origin and positive response to diagnostic nerve blocks. Patients in the radiofrequency treatment group $(n=15)$ received an $80 \mathrm{C}$ radiofrequency lesion of the dorsal ramus of the segmental nerve roots L3, L4, and L5. Patients in the control group $(n=16)$ underwent the same procedure without use of radiofrequency current. A blinded investigator assessed patients' physical impairment, rating of pain, the degree of disability, and quality of life. Eight weeks after treatment, there were 10 success patients in the radiofrequency group and 6 in the sham group. Three, 6, and 12 months after treatment there were more success patients in the radiofrequency group compared to the sham group. At 12 months, 7 of 15 patients in the radiofrequency group were judged as successes versus 2 of 16 in the sham group. The authors concluded that radiofrequency results is significant for short-term and long-term alleviation of pain and functional disability in a select group of patients with chronic low back pain. The study was excluded from the final analysis as it utilized a single diagnostic block utilizing lidocaine $1 \% 0.75 \mathrm{~mL}$ and considered patients who had at least $50 \%$ pain relief to be eligible for study participation.

Leclaire et al (144) in 2001 conducted a randomized, double-blind placebo-controlled trial to assess the efficacy of RFA for low back pain. Patients included in the study $(n=70)$ had low back pain of at least 3 months duration and had a good response to intraarticular facet injections. Patients were randomly assigned to receive either RFA under fluoroscopic guidance $(n=36)$ or the same procedure without denervation (sham procedure) $(n=34)$. Outcome measures were functional disability as assessed by the 
Oswestry and Roland-Morris scales and pain as indicated on a VAS. At 4 weeks, the Roland-Morris score had improved by a mean of $8.4 \%$ in the RFA group and $2.2 \%$ in the placebo group. At 4 weeks, no significant treatment effect was reflected in the Oswestry score or VAS. At 12 weeks, no functional disability treatment effect was reflected in the Oswestry or Roland Morris scale, and no pain reduction was seen as measured by VAS scores. The authors concluded that, although RFA may provide short-term improvement in functional disability, the efficacy of the treatment has not been established. This study differed from other RFA studies in that a functional inventory was the primary outcome, only VAS scores were used to assess pain, and facet injections were used to identify the affected locations. Other studies used diagnostic nerve blocks to identify affected locations. The Leclaire study invited criticism as it failed to define the study population and had inappropriate diagnostic criteria (use of intraarticular injections to identify patients for radiofrequency neurotomy). Patients were evaluated with a single diagnostic block with $50 \%$ pain relief as a criterion standard. They considered any relief of one day duration during a 7-day period following a single diagnostic intraarticular injection as significant. Such an effect may be a result of many factors, including natural sequence. Thus, any results or conclusions based on this study would be erroneous.

van Wijk et al (143) conducted a randomized, double-blind sham lesion-controlled trial to determine the efficacy of radiofrequency facet joint denervation as it is routinely performed. The study was designed to reflect common practice in that although no interventions between trial treatment and 3 months follow-up were performed, further radiofrequency or injection procedures were allowed after this period if the initial treatment did not sufficiently alleviate pain. Patients were randomized to radiofrequency $(n=40)$ or a sham treatment $(n=41)$. The primary outcome was determined with a combined outcome measure comprised of VAS, physical activities and analgesic intake, secondary outcome measures were the separate diary parameters, global perceived effect (i.e., complete relief, $\geq 50 \%$ relief, no effect) of pain increase, and SF-36 Quality of Life Questionnaire. There was no difference between the 2 groups in the combined outcome measure or VAS, although both groups showed improvement in VAS scores. The global perceived effect, however, improved in the radiofrequency group. The researchers observed that the lack of improvement in physical function despite reduction in pain scores underlines the need to combine these procedures with subsequent structured rehabilitation programs. The authors concluded that in selected patients, radiofrequency facet denervation appears to be more effective than sham treatment. However, the van Wijk article was excluded from the review in consideration of several weaknesses. The van Wijk study failed to utilize comparative, controlled diagnostic blocks and reasonable pain relief criteria. The article generated 2 letters to the editor $(164,165)$. Bogduk (164) commented that the radiographs published by van Wijk et al (143) indicates not only that the electrodes were placed perpendicular to the target nerves, but also that they were lateral to the actual location of the nerve. In these locations the lesions produced were destined to fail to coagulate the nerves adequately, if at all. Consequently, the study of van Wijk et al (143) amounts to comparing one sham with another. Gofeld (165) also pointed out that uncontrolled single blocks, such as used in the van Wijk study, yields $27 \%$ false-positive results. Furthermore, he emphasized that the electrodes were 1) definitely not positioned "parallel the nerves"; 2) placed at the base of the transverse process, and not at the base of the superior articular process, and therefore too lateral from the nerve.and 3) too far posteriorly as in the lateral view (that is, on the mamilloaccessory ligament) which insulated medial branches and L5 posterior primary ramus from radiofrequency electrodes. Lastly, the authors had accepted that 22 gauge electrodes with $5-\mathrm{mm}$ active tip could produce insufficient lesion size, but managed to execute lesions using this electrode without position adjustments, thus generating very limited lesions (165).

\section{Level of Evidence}

The indicated level of evidence for radiofrequency neurotomy is Level II-2 to II-3 based on one randomized trial (142), and 2 observational studies $(145,146)$.

\section{Recommendations}

Based on Guyatt et al's criteria (114), the recommendation is $1 \mathrm{~B}$ or $\mathrm{C} /$ strong for radiofrequency neurotomy. 


\section{Discussion}

With comprehensive review of the literature, this systematic review provides current evidence for the effectiveness of lumbar facet or zygapophysial joint interventions in managing chronic low back pain of facet joint origin. Based on the results of this evaluation, the evidence for diagnostic facet joint blocks utilizing $80 \%$ pain relief with controlled diagnostic blocks as a criterion standard is Level I or II-1 based on the USPSTF criteria, utilizing 7 studies which met the inclusion criteria. Based on this evaluation, the prevalence of chronic lumbar facet joint pain related to low back pain is common ranging from $16 \%$ to $41 \%$ with $\mathrm{Cl}$ ranging within $9 \%$ and $49 \%$. The prevalence of false-positive rate with a single block was studied in 6 controlled diagnostic evaluations with a prevalence ranging from $17 \%$ to $49 \%$, with $\mathrm{Cl}$ ranging within $10 \%$ and $59 \%$. A large study (58) showed prevalence of $31 \%$, (95\% Cl $27 \%-36 \%)$ with a false-positive rate of $27 \%(95 \% \mathrm{Cl} 22 \%-32 \%)$ with a single block. Overall prevalence $(n=1,420)$ and false-positive rate of all studies is $31 \%(95 \% \mathrm{Cl} ; 28 \%$ to $33 \%)$ and $30 \%(95 \%$ $\mathrm{Cl} ; 27 \%$ to $33 \%$ ) respectively.

In contrast to the diagnostic interventions, this systematic review found variable evidence for therapeutic facet joint interventions. There was no evidence available for therapeutic intraarticular lumbar facet joint injections. However, the evidence is moderate to strong for therapeutic facet joint nerve blocks and radiofrequency neurotomy with Level II-1 to Level II-3 with 1B or C/strong recommendation for both shortand long-term improvement of chronic low back pain. In the included studies, for both therapeutic modalities, patients were selected based on a positive response to controlled diagnostic blocks and $80 \%$ pain relief as the criterion standard.

Facet arthrosis has been suggested as a cause of low back pain for decades $(29,30)$. However, the exact source of pain in the facet joints is ambiguous. Theories on the generation of pain range from mechanical alterations to vascular changes and molecular signaling. While disc degeneration can clearly cause low back pain, some patients may not experience pain until degenerative changes in the facet joints alter mechanical alignment sufficiently to produce "articular" low back pain (166). Eubanks et al $(30)$ and others $(167,168)$ concluded that evidence of facet arthrosis appears early and can be linked to the amount of heavy work done before age 20. Indeed, it appears that facet arthrosis starts early, with nearly $60 \%$ of adults showing some signs of degenerative changes by the time they reach age 30. After this early rise in arthritic changes, subsequent degeneration appears to steadily increase until the seventh decade when the evidence of arthrosis becomes ubiquitous (30).

A systematic review is defined as, "the application of scientific strategies that limit bias by the systematic assembly, critical appraisal, and synthesis of all relevant studies on a specific topic" $(169,170)$. Systematic reviews are labor intensive and require expertise in both the subject matter and review methods. Thus, expertise in one or other areas is not enough and may lead to inaccurate conclusions in turn leading to inappropriate application of the results (109-113). Thus, this systematic review has provided not only expertise in the subject matter which is crucial, but also knowledge in review methodology. A systematic review differs from a narrative review because a systematic review attempts to minimize bias by the comprehensiveness and reproducibility of the search and selection of articles for review and provides assessment of the methodological quality of the studies (109-113). In this systematic review, we attempted to answer specific narrow clinical questions in depth - the diagnostic accuracy and validity of facet joint blocks and the level of evidence with recommendation for therapeutic facet joint interventions. A systematic searching, selecting, appraising, interpreting, and summarizing of data from original studies was performed. The study summaries were qualitative and quantitative. In this review we have also searched for other types of integrative evidence including other systematic reviews and cost effectiveness studies.

The rationale behind using $50 \%$ pain relief as criteria to proceed to a therapeutic radiofrequency neurotomy was outlined by Schwarzer et al (31) who cite the high incidence of concurrent spinal pathology occurring with lumbar facet joint degeneration as the primary reason. Fujiwara et al (168) found that whereas lumbar degenerative disc disease frequently occurs in absence of lumbar facet joint degeneration, patients with severe lumbar facet joint osteoarthritis virtually always have radiologic evidence of degenerative disc disease and/or other spinal pathology.

Considering that facet joint nerve blocks are inherently nonspecific, even when low volumes are injected under fluoroscopic guidance, a strong case can be made for increasing the criteria to a more stringent $80 \%$ pain relief. A study by Dreyfuss et al (171) found that using $0.5 \mathrm{~mL}$ low volume facet joint nerve 
block using conventional landmarks resulted in contrast spread into the epidural space or intervertebral foramen in $16 \%$ of cases, and between the cleavage plane of the multifidus and longissimus muscles in all injections. Obviously, if $50 \%$ or more relief is used, the prevalence of lumbar facet joint pain will become much higher than the reported values and will range at approximately 60 to $70 \%$ in the lumbar spine $(1-3,38,56-58,60,62,65)$.

Cohen et al (123) emphasized that one reason that double blocks were not used for their study on the success of lumbar zygapophysial joint radiofrequency denervation as a function of diagnostic block relief was that the use of controlled blocks was not cost-effective. Manchikanti et al (172) commented that the whole concept of single blocks resulting with $50 \%$ or more relief followed by radiofrequency denervation creates many questions regarding the reliability of diagnostic blockade, increased health care costs, and coverage for facet joint nerve blocks and radiofrequency neurotomy. Schwarzer et al (38) using $90 \%$ relief of pain as a standard showed that the prevalence of lumbar zygapophysial joint pain in $37 \%$ of patients. The same authors showed a placebo response in $32 \%$ of the patients receiving normal saline. Most publications agree that 2 diagnostic blocks must be performed before radiofrequency denervation and many payors are requiring $80 \%$ or more pain relief. Consequently, a single block will definitely increase costs of care as the single diagnostic block will lead to an increase in number of radiofrequency denervations, which are more expensive and time consuming. Cost effectiveness of controlled, comparative, local anesthetic facet joint nerve blocks has been evaluated and found to be superior to an algorithmic approach starting with discography in axial pain (62).

The most common and worrisome complications of facet joint interventions are related to needle placement and drug administration. Potential complications include dural puncture, spinal cord trauma, infection, intraarterial or intravenous injection, spinal anesthesia, chemical meningitis, neural trauma, pneumothorax, radiation exposure, facet capsule rupture, hematoma formation, and steroid side effects (173-182).

Potential side effects with radiofrequency denervation include painful cutaneous dysesthesias, increased pain due to neuritis or neurogenic inflammation, anesthesia dolorosa, cutaneous hyperesthesia, pneumothorax, and deafferentation pain. Unintentional damage to a spinal nerve during medial branch radiofrequency, causing a motor deficit, is also a complication of a neurolytic procedure (183).

\section{Conclusion}

Diagnostic lumbar facet joint nerve blocks are safe, valid, and reliable. The strength of evidence for diagnostic facet joint techniques is Level I or II-1 based on multiple controlled trials available in the diagnosis of spinal pain in the lumbar region.

For therapeutic interventions, the indicated evidence for lumbar facet joint nerve blocks is Level II1 or II-2 with a 1B or C/strong recommendation. For radiofrequency neurotomy, the indicated evidence is II-2 to II-3 with a recommendation of $1 \mathrm{~B}$ or $1 \mathrm{C}$. The evidence for lumbar intraarticular injections is Level III (limited) with a recommendation of 2 C/very weak recommendation or recommendation not to provide intraarticular injections.

\section{Acknowledgments}

The authors wish to thank the editorial board of Pain Physician, for review and criticism in improving the manuscript; Vidyasagar Pampati, MSc, statistician; Sekar Edem for assistance in search of literature; and Tonie M. Hatton and Diane E. Neihoff, transcriptionists (Pain Management Center of Paducah), for their assistance in the preparation of this manuscript. 


\section{References}

1. Sehgal N, Dunbar EE, Shah RV, Colson J. Systematic review of diagnostic utility of facet (zygapophysial) joint injections in chronic spinal pain: An update. Pain Physician 2007; 10:213-228.

2. Sehgal N, Shah RV, McKenzie-Brown A, Everett CR. Diagnostic utility of facet (zygapophysial) joint injections in chronic spinal pain: A systematic review of evidence. Pain Physician 2005; 8:211-224.

3. Boswell MV, Singh V, Staats PS, Hirsch JA. Accuracy of precision diagnostic blocks in the diagnosis of chronic spinal pain of facet or zygapophysial joint origin: A systematic review. Pain Physician 2003; 6:449-456.

4. Boswell MV, Shah RV, Everett CR, Sehgal N, Mckenzie-Brown AM, Abdi S, Bowman RC, Deer TR, Datta S, Colson JD, Spillane WF, Smith HS, LucasLevin LF, Burton AW, Chopra P, Staats PS, Wasserman RA, Manchikanti L. Interventional techniques in the management of chronic spinal pain: Evidencebased practice guidelines. Pain Physician 2005; 8:1-47.

5. Boswell MV, Colson JD, Spillane WF. Therapeutic facet joint interventions in chronic spinal pain: A systematic review of effectiveness and complications. Pain Physician 2005; 8:101-114.

6. Boswell MV, Colson JD, Sehgal N, Dunbar EE, Epter R. A systematic review of therapeutic facet joint interventions in chronic spinal pain. Pain Physician 2007; 10:229-253.

7. Boswell MV, Trescot AM, Datta S, Schultz DM, Hansen HC, Abdi S, Sehgal N, Shah RV, Singh V, Benyamin RM, Patel VB, Buenaventura RM, Colson JD, Cordner HJ, Epter RS, Jasper JF, Dunbar EE, Atluri SL, Bowman RC, Deer TR, Swicegood JR, Staats PS, Smith HS, Burton AW, Kloth DS, Giordano J, Manchikanti L. Interventional techniques: Evidencebased practice guidelines in the management of chronic spinal pain. Pain Physician 2007; 10:7-111.

8. Marks RC. Distribution of pain provoked from lumbar facet joints and related structures during diagnostic spinal infiltration. Pain 1989; 39:37-40.

9. Fukui S, Ohseto K, Shiotani M, Ohno K, Karasawa $\mathrm{H}$, Naganuma Y. Distribution of referred pain from the lumbar zygapophyseal joints and dorsal rami. Clin J Pain 1997; 13:303-307.
10. Hirsch C, Ingelmark BE, Miller M. The anatomical basis for low back pain. Studies on the presence of sensory nerve endings in ligamentous, capsular and intervertebral disc structures in the human lumbar spine. Acta Orthop Scand 1963; 33:1-17.

11. Windsor RE, King FJ, Roman SJ, Tata NS, Cone-Sullivan LA, Thmapi S, Acebey M, Gilhool JJ, Rao R, Sugar R. Electrical stimulation induced lumbar medial branch referral patterns. Pain Physician 2002; 5:347-353.

12. Mooney V, Robertson J. The facet syndrome. Clin Orthop Relat Res 1976; 115:149-156.

13. McCall IW, Park WM, O'Brien JP. Induced pain referral from posterior lumbar elements in normal subjects. Spine 1979; 4:441-446.

14. Cavanaugh JM, Lu Y, Chen C, Kallakuri S. Pain generation in lumbar and cervical facet joints. J Bone Joint Surg Am 2006; 88:63-67.

15. Masini M, Paiva WS, Araujo AS, Jr. Anatomical description of the facet joint innervation and its implication in the treatment of recurrent back pain. J Neurosurg Sci 2005; 49:143-146.

16. Konnai Y, Honda T, Sekiguchi Y, Kikuchi $S$, Sugiura Y. Sensory innervation of the lumbar dura mater passing through the sympathetic trunk in rats. Spine 2000; 25:776-782.

17. Suseki K, Takahashi Y, Takahashi K, Chiba T, Tanaka K, Morinaga T, Nakamura $\mathrm{S}$, Moriya $\mathrm{H}$. Innervation of the lumbar facet joints. Origins and functions. Spine 1997; 22:477-485.

18. Bogduk N, Wilson AS, Tynan W. The human lumbar dorsal rami. J Anat 1982; 134:383-397.

19. Cavanaugh JM, Ozaktay AC, Yamashita T, Avramov A, Getchell TV, King Al. Mechanisms of low back pain: A neurophysiologic and neuroanatomic study. Clin Orthop Relat Res 1997; 335:166180.

20. Miyagi $M$, Ohtori $S$, Ishikawa $T$, Aoki $\mathrm{Y}$, Ozawa T, Doya H, Saito T, Moriya H, Takahashi K. Up-regulation of TNFalpha in DRG satellite cells following lumbar facet joint injury in rats. Eur Spine J 2006; 15:953-958.

21. Ohtori S, Takahashi K, Chiba T, Yamagata M, Sameda H, Moriya H. Substance $P$ and calcitonin gene-related peptide immunoreactive sensory DRG neurons innervating the lumbar facet joints in rats. Auton Neurosci 2000; 86:13-17.

22. Suseki K, Takahashi Y, Takahashi K, Chiba T, Tanaka K, Moriya H. CGRP-immunoreactive nerve fibers projecting to lumbar facet joints through the paravertebral sympathetic trunk in rats. Neurosci Lett 1996; 221:41-44.

23. Ohtori S, Takahashi K, Chiba T, Yamagata M, Sameda H, Moriya H. Brain-derived neurotrophic factor and vanilloid receptor subtype 1 immunoreactive sensory DRG neurons innervating the lumbar facet joints in rats. Auton Neurosci 2001; 94:132-135.

24. Yamashita T, Cavanaugh J, el-Bohy AA, Getchell TV, King Al. Mechanosensitive afferent units in the lumbar facet joint. J Bone Joint Surg Am 1990; 72:865-870.

25. Yamashita T, Cavanaugh JM, Ozaktay AC, Avramov Al, Getchell TV, King Al. Effect of substance $P$ on mechanosensitive units of tissues around and in the lumbar facet joint. J Orthop Res 1993; 11:205-214.

26. Beaman DN, Graziano GP, Glover RA, Wojtys EM, Chang V. Substance P innervation of lumbar spine facet joints. Spine 1993; 18:1044-1049.

27. Ohtori S, Takahashi K, Chiba T, Yamagata $M$, Sameda H, Moriya H. Phenotypic inflammation switch in rats shown by calcitonin gene-related peptide immunoreactive dorsal root ganglion neurons innervating the lumbar facet joints. Spine 2001; 26:1009-1013.

28. Ishikawa $T$, Miyagi $M$, Ohtori $S$, Aoki Y, Ozawa T, Doya H, Saito T, Moriya H, Takahashi K. Characteristics of sensory DRG neurons innervating the lumbar facet joints in rats. Eur Spine J 2005; 14:559-564.

29. Kalichman L, Li L, Kim DH, Guermazi A, Berkin V, O'Donnell CJ, Hoffmann U, Cole R, Hunter DJ. Facet joint osteoarthritis and low back pain in the community-based population. Spine 2008; 33:2560-2565.

30. Eubanks JD, Lee MJ, Cassinelli E, Ahn NU. Prevalence of lumbar facet arthrosis and its relationship to age, sex, and race: An anatomic study of cadaveric specimens. Spine 2007; 32:20582062.

31. Schwarzer AC, Aprill C, Derby R, Fortin J, Kine G, Bogduk N. Clinical features of patients with pain stemming from the lumbar zygapophyseal joints. Is the 
lumbar facet syndrome a clinical entity? Spine 1994; 10:1132-1137.

32. Schwarzer AC, Wang SC, O'Driscoll $D$, Harrington T, Bogduk N, Laurent R. The ability of computed tomography to identify a painful zygapophysial joint in patients with chronic low back pain. Spine 1995; 20:907-912.

33. Bogduk N. International Spinal Injection Society guidelines for the performance of spinal injection procedures. Part 1: Zygapophysial joint blocks. Clin J Pain 1997; 13:285-302.

34. Nachemson AL. Newest knowledge of low-back pain: A critical look. Clin Orthop 1992; 179:8-20.

35. Badgley CE. The articular facets in relation to low-back pain and sciatic radiation. J Bone Joint Surg 1941; 23:481496.

36. Manchikanti L, Pampati V, Fellows B, Bakhit CE. Prevalence of facet joint pain in chronic low back pain. Pain Physician 1999; 2:59-64.

37. Manchikanti L, Pampati V, Fellows B, Bakhit CE. The diagnostic validity and therapeutic value of medial branch blocks with or without adjuvants. Curr Rev Pain 2000; 4:337-344.

38. Schwarzer AC, Wang S, Bogduk N, McNaught PJ, Laurent R. Prevalence and clinical features of lumbar zygapophysial joint pain: A study in an Australian population with chronic low back pain Ann Rheum Dis 1995; 54:100-106.

39. Jackson RP, Jacobs RR, Montesano PX. Facet joint injection in low back pain: A prospective study. Spine 1988; 13:966971.

40. Selby DK, Paris SV. Anatomy of facet joints and its correlation with low back pain. Contemp Orthop 1981; 312:10971103.

41. Raymond J, Dumas JM. Intraarticular facet block. Diagnostic tests or therapeutic procedure? Radiology 1989; 151:333-336.

42. Deyo RA, Weinstein JN. Low back pain. N Engl J Med 2001; 344:363-370.

43. Deyo RA, Rainville J, Kent DL. What can the history and physical examination tell us about low back pain? JAMA 1992; 268:760-765.

44. Don AS, Carragee EJ. Is the self-reported history accurate in patients with persistent axial pain after a motor vehicle accident? Spine J 2009; 9:4-12.

45. Carragee EJ. Validity of self-reported history in patients with acute back or neck pain after motor vehicle acci- dents. Spine J 2008; 8:311-319.

46. Schwarzer AC, Derby R, Aprill CN, Fortin J, Kine G, Bogduk N. Pain from the lumbar zygapophysial joints: A test of two models. J Spinal Disord 1994; 7:331336.

47. Hancock MJ, Maher CG, Latimer J, Spindler MF, McAuley JH, Laslett M, Bogduk N. Systematic review of tests to identify the disc, SIJ or facet joint as the source of low back pain. Eur Spine J 2007; 16:1539-1550.

48. Laslett M, McDonald B, Aprill CN, Tropp H, Oberg B. Clinical predictors of screening lumbar zygapophyseal joint blocks: Development of clinical prediction rules. Spine J 2006; 6:370-379.

49. Laslett M, McDonald B, Tropp H, Aprill $\mathrm{CN}$, Oberg B. Agreement between diagnoses reached by clinical examination and available reference standards: A prospective study of 216 patients with lumbopelvic pain. BMC Musuloskeletal Disord 2005; 6:28-37.

50. Pneumaticos SG, Chatziioannou SN, Hipp JA, Moore WH, Esses SI. Low back pain: Prediction of short-term outcome of facet joint injection with bone scintigraphy. Radiology 2006; 238:693698.

51. Manchikanti L, Pampati V, Fellows B, Baha GA. The inability of the clinical picture to characterize pain from facet joints. Pain Physician 2000; 3:158-166.

52. Revel ME, Listrat VM, Chevalier XJ, Dougados $M$, N'Guyen MP, Vallee C, Wybier $M$, Gires F, Amor B. Facet joint block for low back pain: Identifying predictors of a good response. Arch Phys Med Rehabil 1992; 73:824-828.

53. Revel ME, Poiraudeau S, Auleley GR, Payan C, Denke A, Nguyen M, Chev$\operatorname{rot} A$, Fermanian J. Capacity of the clinical picture to characterize low back pain relieved by facet joint anesthesia. Proposed criteria to identify patients with painful facet joints. Spine 1998; 23:1972-1976.

54. Laslett M, Oberg B, Aprill CN, McDonald B. Zygapophysial joint blocks in chronic low back pain: A test of Revel's model as a screening test. BMC Musuloskeletal Disord 2004; 5:43-48.

55. Young S, Aprill C, Laslett M. Correlation of clinical examination characteristics with three sources of chronic low back pain. Spine J 2003; 3:460-465.

56. Manchikanti L, Hirsch JA, Pampati V. Chronic low back pain of facet (zygapophysial) joint origin: Is there a dif- ference based on involvement of single or multiple spinal regions? Pain Physician 2003; 6:399-405.

57. Manchikanti L, Singh V, Pampati V, Damron KS, Beyer CD, Barnhill RC. Is there correlation of facet joint pain in lumbar and cervical spine? An evaluation of prevalence in combined chronic low back and neck pain. Pain Physician 2002; 5:365-371.

58. Manchikanti L, Boswell MV, Singh V, Pampati V, Damron KS, Beyer CD. Prevalence of facet joint pain in chronic spinal pain of cervical, thoracic, and lumbar regions. BMC Musuloskeletal Disord 2004; 5:15.

59. Manchikanti L, Pampati V, Singh V, Beyer C, Damron K, Fellows B. Evaluation of role of facet joints in persistent low back pain in obesity: A controlled, prospective, comparative evaluation. Pain Physician 2001; 4:266-272.

60. Manchukonda R, Manchikanti KN, Cash KA, Pampati V, Manchikanti L. Facet joint pain in chronic spinal pain: An evaluation of prevalence and false-positive rate of diagnostic blocks. J Spinal Disord Tech 2007; 20:539-545.

61. Schwarzer AC, Aprill CN, Derby R, Fortin J, Kine G, Bogduk N. The false-positive rate of uncontrolled diagnostic blocks of the lumbar zygapophysial joints. Pain 1994; 58:195-200.

62. Manchikanti L, Singh V, Pampati V, Damron KS, Barnhill RC, Beyer C, Cash $\mathrm{KA}$. Evaluation of the relative contributions of various structures in chronic low back pain. Pain Physician 2001; 4:308-316.

63. Manchikanti L, Manchikanti K, Cash KA, Singh V, Giordano J. Age-related prevalence of facet joint involvement in chronic neck and low back pain. Pain Physician 2008; 11:67-75.

64. Manchikanti L, Cash KA, Pampati V, Fellows B. Influence of psychological variables on the diagnosis of facet joint involvement in chronic spinal pain. Pain Physician 2008; 11:145-160.

65. Manchikanti L, Manchukonda R, Pampati V, Damron KS, McManus CD. Prevalence of facet joint pain in chronic low back pain in postsurgical patients by controlled comparative local anesthetic blocks. Arch Phys Med Rehabil 2007; 88:449-455.

66. Rubinstein SM, van Tulder M. A best-evidence review of diagnostic procedures for neck and low-back pain. Best Pract Res Clin Rheumatol 2008; 22:471-482. 
67. Barnsley L, Lord S, Bogduk N. Comparative local anaesthetic blocks in the diagnosis of cervical zygapophysial joint pain. Pain 1993; 55:99-106.

68. Boas RA. Nerve blocks in the diagnosis of low back pain. Neurosurg Clin N Am 1991; 2:807-816.

69. Bonica JJ, Buckley FP. Regional analgesia with local anesthetics. In: Bonica JJ (ed). The Management of Pain. Lea \& Febiger, Philadelphia, 1990; 2:18831966.

70. Lord SM, Barnsley L, Bogduk N. The utility of comparative local anesthetic blocks versus placebo-controlled blocks for the diagnosis of cervical zygapophysial joint pain. Clin J Pain 1995; 11:208-213.

71. North RB, Kidd DH, Zahurak M, Piantadosi S. Specificity of diagnostic nerve blocks: A prospective, randomized study of sciatica due to lumbosacral spine disease. Pain 1996; 65:77-85.

72. Hogan QH, Abram SE. Neural blockade for diagnosis and prognosis. A review. Anesthesiology 1997; 86:216-241.

73. Hildebrandt J. Relevance of nerve blocks in treating and diagnosing low back pain - Is the quality decisive? Schmerz 2001; 15:474-483.

74. Saal JS. General principles of diagnostic testing as related to painful lumbar spine disorders: A critical appraisal of current diagnostic techniques. Spine 2002; 27:2538-2545.

75. Cohen SP, Raja SN. Pathogenesis, diagnosis, and treatment of lumbar zygapophysial (facet) joint pain. Anesthesiology 2007; 106:591-614.

76. Ackerman WE, Munir MA, Zhang JM, Ghaleb A. Are diagnostic lumbar facet injections influenced by pain of muscular origin? Pain Pract 2004; 4:286-291.

77. Leonardi M, Pfirrmann CW, Boos N. Injection studies in spinal disorders. Clin Orthop Relat Res 2006; 443:168-182.

78. Waggershauser T, Schwarzkopf S, Reiser M. Facet blockade, peridural and periradicular pain therapy. Radiologe 2006; 46:520-526.

79. Resnick DK, Choudhri TF, Dailey AT, Groff MW, Khoo L, Matz PG, Mummaneni P, Watters WC 3rd, Wang J, Walters BC, Hadley MN; American Association of Neurological Surgeons/Congress of Neurological Surgeons. Guidelines for the performance of fusion procedures for degenerative disease of the lumbar spine. Part 7: Intractable low-back pain without stenosis or spondylolisthesis. J Neurosurg Spine 2005; 2:670-672.

80. Geurts JW, van Wijk RM, Stolker RJ, Groen GJ. Efficacy of radiofrequency procedures for the treatment of spinal pain: A systematic review of randomized clinical trials. Reg Anesth Pain Med 2001; 26:394-400.

81. Niemisto L, Kalso E, Malmivaara A, Seitsalo S, Hurri H. Radiofrequency denervation for neck and back pain: A systematic review within the framework of the cochrane collaboration back review group. Spine 2003; 28:1877-1888.

82. Staal JB, de Bie R, de Vet HC, Hildebrandt J, Nelemans P. Injection therapy for subacute and chronic low back pain: An updated Cochrane review. Spine 2009; 34:49-59.

83. Manchikanti L, Singh V, Vilims BD, Hansen HC, Schultz DM, Kloth DS. Medial branch neurotomy in management of chronic spinal pain: Systematic review of the evidence. Pain Physician 2002 5:405-418.

84. Nelemans PJ, deBie RA, deVet HC, Sturmans F. Injection therapy for subacute and chronic benign low back pain. Spine 2001; 26:501-515.

85. Manchikanti L, Singh V, Derby R, Schultz DM, Benyamin RM, Prager JP, Hirsch JA. Reassessment of evidence synthesis of occupational medicine practice guidelines for interventional pain management. Pain Physician 2008; 11:393482.

86. Falco FJE, Erhart S, Wargo BW, Bryce DA, Atluri S, Datta S, Hayek SM. Systematic review of diagnostic utility and therapeutic effectiveness of cervical facet joint interventions. Pain Physician 2009; 12:323-344.

87. Bogduk N. A narrative review of intraarticular corticosteroid injections for low back pain. Pain Med 2005; 6:287-296.

88. West S, King V, Carey T, Lohr K, McKoy N, Sutton S, Lux L. Systems to Rate the Strength of Scientific Evidence, Evidence Report, Technology Assessment No. 47 AHRQ Publication No. 02-E016. Rockville, MD: Agency for Healthcare Research and Quality, 2002.

89. Manchikanti L, Dunbar EE, Wargo BW Shah RV, Derby $r$, cohen sp. systematic review of cervical discography as a diagnostic test for chronic spinal pain. pain physician 2009; 12:305-321.

90. Singh V, Manchikanti L, Shah RV, Dunbar EE, Glaser SE. Systematic review of thoracic discography as a diagnostic test for chronic spinal pain. Pain Physician 2008; 11:631-642.

91. Wolfer L, Derby R, Lee JE, Lee SH. Systematic review of lumbar provocation discography in asymptomatic subjects with a meta-analysis of false-positive rates. Pain Physician 2008; 11:513538.

92. Rupert MP, Lee M, Manchikanti L, Datta S, Cohen SP. Evaluation of sacroiliac joint interventions: A systematic appraisal of the literature. Pain Physician 2009; 12:399-418..

93. Atluri S, Datta S, Falco FJ, Lee M. Systematic review of diagnostic utility and therapeutic effectiveness of thoracic facet joint interventions. Pain Physician 2008; 11:611-629.

94. Smith HS, Chopra P, Patel VB, Frey ME, Rastogi R. Systematic review on the role of sedation in diagnostic spinal interventional techniques. Pain Physician 2009; 12:195-206.

95. Berg AO, Allan JD. Introducing the third U.S. Preventive Services Task Force. Am J Prev Med 2001; 20:S3-S4.

96. Koes B, Scholten R, Mens J, Bouter L. Efficacy of epidural steroid injections for low-back pain and sciatica: A systematic review of randomized clinical trials. Pain 1995; 63:279-288.

97. Buenaventura RM, Datta S, Abdi S, Smith HS. Systematic review of therapeutic lumbar transforaminal epidural steroid injections. Pain Physician 2009; 12:233-251.

98. Parr AT, Diwan S, Abdi S. Lumbar interlaminar epidural injections in managing chronic low back and lower extremity pain: A systematic review. Pain Physician 2009; 12:163-188.

99. Helm S, Hayek SM, Benyamin RM, Manchikanti L. Systematic review of the effectiveness of thermal annular procedures in treating discogenic low back pain. Pain Physician 2009; 12:207-232.

100. Conn A, Buenaventura RM, Datta S, Abdi S, Diwan S. Systematic review of caudal epidural injections in the management of chronic low back pain. Pain Physician 2009; 12:109-135.

101. Benyamin RM, Singh V, Parr AT, Conn A, Diwan S, Abdi S. Systematic review of the effectiveness of cervical epidurals in the management of chronic neck pain. Pain Physician 2009; 12:137-157.

102. Frey ME, Manchikanti L, Benyamin RM, 
Schultz DM, Smith HS, Cohen SP. Spinal cord stimulation for patients with failed back surgery syndrome: A systematic review. Pain Physician 2009; 12:379-397.

103. Patel VB, Manchikanti L, Singh V, Schultz DM, Hayek SM, Smith HS. Systematic review of intrathecal infusion systems for long-term management of chronic non-cancer pain. Pain Physician 2009; 12:345-360..

104. Epter RS, Helm S, Hayek SM, Benyamin RM, Smith HS, Abdi S. Systematic review of percutaneous adhesiolysis and management of chronic low back pain in post lumbar surgery syndrome. Pain Physician 2009; 12:361-378.

105. Hayek SM, Helm S, Benyamin RM, Singh V, Bryce DA, Smith HS. Effectiveness of spinal endoscopic adhesiolysis in post lumbar surgery syndrome: A systematic review. Pain Physician 2009; 12:419-435.

106. van Tulder $M$, Furlan $A$, Bombardier C, Bouter L, Editorial Board of the Cochrane Collaboration Back Review Group. Updated method guidelines for systematic reviews in the Cochrane Collaboration Back Review Group. Spine 2003; 28:1290-1299.

107. Salaffi $F$, Stancati $A$, Silvestri $C A$, Ciapetti A, Grassi W. Minimal clinically important changes in chronic musculoskeletal pain intensity measured on a numerical rating scale. Eur J Pain 2004; 8:283-291.

108. Bombardier C. Outcome assessments in the evaluation of treatment of spinal disorders: Summary and general recommendations. Spine 2000; 25:31003103.

109. Manchikanti L. Evidence-based medicine, systematic reviews, and guidelines in interventional pain management: Part 1: Introduction and general considerations. Pain Physician 2008; 11:161-186.

110. Manchikanti L, Hirsch JA, Smith HS. Evidence-based medicine, systematic reviews, and guidelines in interventional pain management: Part 2: Randomized controlled trials. Pain Physician 2008; 11:717-773.

111. Manchikanti L, Singh V, Smith HS, Hirsch JA. Evidence-based medicine, systematic reviews, and guidelines in interventional pain management: Part 4: Observational studies. Pain Physician 2009; 12:73-108.

112. Manchikanti L, Benyamin RM, Helm S,
Hirsch JA. Evidence-based medicine, systematic reviews, and guidelines in interventional pain management: Part 3: Systematic reviews and meta-analyses of randomized trials. Pain Physician 2009; 12:35-72.

113. Manchikanti L, Boswell MV, Giordano J. Evidence-based interventional pain management: Principles, problems, potential, and applications. Pain Physician 2007; 10:329-356.

114. Guyatt $G$, Gutterman $D$, Baumann $M H$, Addrizzo-Harris $D$, Hylek EM, Phillips B, Raskob G, Lewis SZ, Schünemann $\mathrm{H}$. Grading strength of recommendations and quality of evidence in clinical guidelines: Report from an American College of Chest Physicians task force. Chest 2006; 129:174-181.

115. Manchikanti L, Pampati V, Fellows $B$ Rivera JJ, Damron KS, Beyer CD, Cash $K A$. Influence of psychological factors on the ability to diagnose chronic low back pain of facet joint origin. Pain Physician 2001; 4:349-357.

116. Mayer TG, Gatchel RJ, Keeley J, MCGeary D, Dersh J, Anagnostis C. A randomized clinical trial of treatment for lumbar segmental rigidity. Spine 2004 29:2199-2205.

117. Ackerman WE, 3rd, Ahmad M. Pain relief with intraarticular or medial branch nerve blocks in patients with positive lumbar facet joint SPECT imaging: a 12-week outcome study. South Med J 2008; 101:931-934.

118. Manchikanti L, Pampati V, Damron KS, McManus CD, Jackson SD, Barnhill RC, Martin JC. The effect of sedation on diagnostic validity of facet joint nerve blocks: An evaluation to assess similarities in population with involvement in cervical and lumbar regions (ISRCTNo:76376497). Pain Physician 2006; 9:47-52.

119. Manchikanti L, Damron KS, Rivera J, McManus CD, Jackson SD, Barnhill RC, Martin JC. Evaluation of effect of sedation as a confounding factor in the diagnostic validity of lumbar facet joint pain: A prospective, randomized, double-blind, placebo-controlled evaluation. Pain Physician 2004; 7:411-417.

120. Manchikanti L, Pampati V, Damron K. The role of placebo and nocebo effects of perioperative administration of sedatives and opioids in interventional pain management. Pain Physician 2005; 8:349-355.

121. Manchikanti L, Singh V, Pampati V.
Are diagnostic lumbar medial branch blocks valid? Results of 2-year followup. Pain Physician 2003; 6:147-153.

122. Manchikanti L, Pampati V, Rivera JJ, Fellows B, Beyer CD, Damron KS. Role of facet joints in chronic low back pain in the elderly: A controlled comparative prevalence study. Pain Practice 2001; 1:332-337.

123. Cohen SP, Stojanovic MP, Crooks M, Kim P, Schmidt RK, Shields $\mathrm{CH}$, Croll S, Hurley RW. Lumbar zygapophysial (facet) joint radiofrequency denervation success as a function of pain relief during diagnostic medial branch blocks: A multicenter analysis. Spine J 2008; 8:498-504.

124. Manchikanti L, Singh V, Fellows B, Pampati V. Evaluation of influence of gender, occupational injury, and smoking on chronic low back pain of facet joint origin: A subgroup analysis. Pain Physician 2002; 5:30-35.

125. Murtagh FR. Computed tomography and fluoroscopy guided anesthesia and steroid injection in facet syndrome. Spine 1988; 13:686-689.

126. Destouet JM, Gilula LA, Murphy WA, Monsees B. Lumbar facet joint injection: indication, technique, clinical correlation, and preliminary results. Radiology 1982; 145:321-325.

127. Lewinnek GE, Warfield CA. Facet joint degeneration as a cause of low back pain. Clin Orthop Relat Res 1986; 213:216-222.

128. Carrera GF, Williams AL. Current concepts in evaluation of the lumbar facet joints. Crit Rev Diagn Imaging 1984; 21:85-104.

129. Lippitt $A B$. The facet joint and its role in spine pain. Management with facet joint injections. Spine 1984; 9:746750.

130. Gorbach C, Schmid MR, Elfering A, Hodler J, Boos N. Therapeutic efficacy of facet joint blocks. Am J Roentgenol 2006; 186:1228-1233.

131. Fairbank JC, Park WM, McCall IW, O'Brien JP. Apophyseal injection of local anesthetic as a diagnostic aid in primary low-back pain syndromes. Spine 1981; 6:598-605.

132. Carette $S$, Marcoux $S$, Truchon R, Grondin C, Gagnon J, Allard Y, Latulippe M. A controlled trial of corticosteroid injections into facet joints for chronic low back pain. N Engl J Med 1991; 325:1002-1007. 
133. Lilius $G$, Laasonen EM, Myllynen $P_{1}$ Harilainen A, Gronlund G. Lumbar facet joint syndrome. A randomised clinical trial. J Bone Joint Surg Br 1989; 71:681684.

134. Fuchs S, Erbe T, Fischer HL, Tibesku CO. Intraarticular hyaluronic acid versus glucocorticoid injections for nonradicular pain in the lumbar spine. J Vasc Interv Radiol 2005; 16:1493-1498.

135. Marks RC, Houston T, Thulbourne T. Facet joint injection and facet nerve block: A randomised comparison in 86 patients with chronic low back pain. Pain 1992; 49:325-328.

136. Nash TP. Facet joints. Intra-articular steroids or nerve blocks? Pain Clinic 1990; 3:77-82.

137. Fuchs $S$, Mönikes $R$, Wohlmeiner $A$, Heyse T. Intra-articular hyaluronic acid compared with corticoid injections for the treatment of rhizarthrosis. Osteoarthritis Cartilage 2006; 14:82-88.

138. Cleary M, Keating C, Poynton AR. Viscosupplementation in lumbar facet joint arthropathy: A pilot study. J Spinal Disord Tech 2008; 21:29-32.

139. Manchikanti L, Manchikanti K, Manchukonda R, Cash KA, Damron KS, Pampati V, McManus CD. Evaluation of lumbar facet joint nerve blocks in the management of chronic low back pain: A preliminary report of a randomized, double-blind controlled trial. Clinical Trial NCT000355914. Pain Physician 2007; 10:425-440.

140. Manchikanti L, Singh V, Falco FJ, Cash KA, Pampati V. Lumbar facet joint nerve blocks in managing chronic facet joint pain: One-year follow-up of a randomized, double-blind controlled trial: Clinical Trial NCT00355914. Pain Physician 2008; 11:121-132.

141. Manchikanti L, Pampati V, Bakhit C, Rivera J, Beyer C, Damron K, Barnhill R. Effectiveness of lumbar facet joint nerve blocks in chronic low back pain: A randomized clinical trial. Pain Physician 2001; 4:101-117.

142. Nath S, Nath CA, Pettersson K. Percutaneous lumbar zygapophysial (facet) joint neurotomy using radiofrequency current, in the management of chronic low back pain: A randomized doubleblind trial. Spine 2008; 33:1291-1298.

143. van Wijk RM, Geurts JW, Wynne HJ, Hammink E, Buskens E, Lousberg R, Knape JT, Groen GJ. Radiofrequency denervation of lumbar facet joints in the treatment of chronic low back pain: A randomized, double-blind, sham lesion-controlled trial. Clin J Pain 2005; 21:335-344.

144. Leclaire R, Fortin L, Lambert R, Bergeron $Y M$, Rossignol M. Radiofrequency facet joint denervation in the treatment of low back pain: A placebo-controlled clinical trial to assess efficacy. Spine 2001; 26:1411-1416.

145. Gofeld M, Jitendra J, Faclier G. Radiofrequency facet denervation of the lumbar zygapophysial joints: 10-year prospective clinical audit. Pain Physician 2007; 10:291-300.

146. Dreyfuss $P$, Halbrook B, Pauza K, Joshi A, McLarty J, Bogduk N. Efficacy and validity of radiofrequency neurotomy for chronic lumbar zygapophysial joint pain. Spine 2000; 25:1270-1277.

147. Gallagher J, Petriccione Di Vadi PL, Wedley JR, Hamann W, Ryan P, Chikanza I, Kirkham B, Price R, Watson MS, Grahame R, Wood S. Radiofrequency facet joint denervation in the treatment of low back pain: A prospective controlled double-blind study to assess its efficacy. Pain Clinic 1994; 7:193-198.

148. Sanders M, Zuurmond WWA. Percutaneous intraarticular lumbar facet joint denervation in the treatment of low back pain: A comparison with percutaneous extra-articular lumbar facet denervation Pain Clinic 1999; 11:329-335.

149. Buijs EJ, van Wijk RM, Geurts JW, Weeseman RR, Stolker RJ, Groen GG. Radiofrequency lumbar facet denervation: $A$ comparative study of the reproducibility of lesion size after 2 current radiofrequency techniques. Reg Anesth Pain Med 2004; 29:400-407.

150. van Kleef $M$, Barendse GAM, Kessels $A$ Voets HM, Weber WE, de Lange S. Randomized trial of radiofrequency lumbar facet denervation for chronic low back pain. Spine 1999; 24:1937-1942.

151. Shih C, Lin GY, Yueh KC, Lin JJ. Lumbar zygapophyseal joint injections in patients with chronic lower back pain. J Chin Med Assoc 2005; 68:59-64.

152. Schulte $T L$, Pietila $T A$, Heidenreich J, Brock M, Stendel R. Injection therapy of lumbar facet syndrome: A prospective study. Acta Neurochir (Wien) 2006; 148:1165-1172.

153. Lynch MC, Taylor JF. Facet joint injection for low back pain: A clinical study. J Bone Joint Surg Br 1986; 68:138-141.

154. Lau LS, Littlejohn GO, Miller MH. Clinical evaluation of intraarticular injections for lumbar facet joint pain. Med J
Aust 1985; 143:563-565.

155. Tekin I, Mirzai H, Ok G, Erbuyun K, Vatansever D. A comparison of conventional and pulsed radiofrequency denervation in the treatment of chronic facet joint pain. Clin J Pain 2007; 23:524-529.

156. Vad VB, Cano WG, Basrai D, Lutz GE, Bhat $A L$. Role of radiofrequency denervation in lumbar zygapophyseal joint synovitis in baseball pitchers: A clinical experience. Pain Physician 2003; 6:307-312.

157. Mogalles AA, Dreval ON, Akatov OV, Kuznetsov AV, Rynkov IP, Plotnikov VM, Minaev VP. Percutaneous laser denervation of the zygapophyseal joints in the pain facet syndrome. Zh Vopr Neirokhir Im N N Burdenko 2004; 1:20-25.

158. Birkenmaier $C$, Veihelmann A, Trouillier $\mathrm{H}$, Hausdorf J, Devens C, Wegener $B$, Jansson V, von Schulze Pellengahr C. Percutaneous cryodenervation of lumbar facet joints: A prospective clinical trial. Int Orthop 2006; Aug 23. [Epub ahead of print].

159. Staender M, Maerz U, Tonn JC, Steude U. Computerized tomography-guided kryorhizotomy in 76 patients with lumbar facet joint syndrome. I Neurosurg Spine 2005; 3:444-449.

160. Blanchard J, Ramamurthy S, Walsh N, Hoffman J, Schoenfeld L. Intravenous regional sympatholysis: A double-blind comparison of guanethidine, reserpine, and normal saline. J Pain Symptom Manage 1990; 5:357-361.

161. Frost FA, Jessen $B$, Siggaard-Andersen J. A control, double-blind comparison of mepivacaine injection versus saline injection for myofascial pain. Lancet 1980; 1:499-500.

162. Price DD, Long S, Wilsey B, Rafii A. Analysis of peak magnitude and duration of analgesia produced by local anesthetics injected into sympathetic ganglia of complex regional pain syndrome patients. Clin J Pain 1998; 14:216-226.

163. Bogduk N. Point of view. Spine 2008; 33:1298.

164. Bogduk N. Lumbar radiofrequency neurotomy. Clin J Pain 2006; 22:409.

165. Gofeld M. Radiofrequency facet denervation: A randomized control placebo versus sham procedure. Clin J Pain. 2006; 22:410-411.

166. Giles LG, Taylor JR. Osteoarthrosis in human cadaveric lumbo-sacral zygapophyseal joints. I Manipulative 
Physiol Ther 1985; 8:239-243.

167. Lewin T. Osteoarthritis in lumbar synovial joints. A morphologic study. Acta Orthop Scand Suppl 1964; 73:71-112.

168. Fujiwara A, Tamai K, Yamato M, An HS, Yoshida $H$, Saotome K, Kurihashi A. The relationship between facet joint osteoarthritis and disc degeneration of the lumbar spine: An MRI study. Eur Spine J 1999; 8:396-401.

169. Cook DJ, Greengold NL, Ellrodt AG, Weingarten SR. The relation between systematic reviews and practice guidelines. Ann Intern Med 1997; 127:210216.

170. Cook DJ, Mulrow CD, Haynes RB. Systematic reviews: Synthesis of best evidence for clinical decisions. Ann Intern Med 1997; 126:376-380.

171. Dreyfuss P, Schwarzer AC, Lau P, Bogduk N. Specificity of lumbar medial branch and $\mathrm{L} 5$ dorsal ramus blocks. A computed tomography study. Spine 1997; 22:895-902.

172. Manchikanti L, Singh V. Diagnosis of facet joint pain and prediction of suc- cess and failure for cervical facet radiofrequency denervation. Reg Anesth Pain Med 2009; 34:81-82.

173. Magee $M$, Kannangara S, Dennien $B$ Lonergan R, Emmett L, Van der WH. Paraspinal abscess complicating facet joint injection. Clin Nucl Med 2000; 25:71-73.

174. Windsor RE, Pinzon EG, Gore H C. Complications of common selective spinal injections: Prevention and management. Am J Orthop 2000; 29:759-770.

175. Marks RC, Semple AJ. Spinal anaesthesia after facet joint injection. Anaesthe sia 1988; 43:65-66.

176. Cook NJ, Hanrahan P, Song S. Paraspinal abscess following facet joint injection. Clin Rheumatol 1999; 18:52-53.

177. Manchikanti L, Cash KA, Moss TL, Rivera J, Pampati V. Risk of whole body radiation exposure and protective measures in fluoroscopically guided interventional techniques: A prospective evaluation. BMC Anesthesiol 2003; 3:1-9.

178. Berrigan T. Chemical meningism after lumbar facet joint block. Anaesthesia 1992; 47:905-906.

179. Thomson SJ, Lomax DM, Collett BJ. Chemical meningism after lumbar facet joint block with local anaesthetic and steroids. Anaesthesia 1993; 46:563564.

180. Raj PP, Shah RV, Kaye AD, Denaro S, Hoover JM. Bleeding risk in interventional pain practice: Assessment, management, and review of the literature. Pain Physician 2004; 7:3-51.

181. Simopoulos TT, Kraemer JJ, Glazer P, Bajwa ZH. Vertebral osteomyelitis: A potentially catastrophic outcome after lumbar epidural steroid injection. Pain Physician 2008; 11:693-697.

182. Benyamin RM, Vallejo R, Kramer J, Rafeyan. Corticosteroid induced psychosis in the pain management setting. Pain Physician 2008; 11:917-920.

183. Kornick C, Kramarich SS, Lamer TJ, Todd Sitzman B. Complications of lumbar facet radiofrequency denervation. Spine 2004; 29:1352-1354. 